\title{
Traumatic Brain Injury Broadly Affects GABAergic Signaling in Dentate Gyrus Granule Cells
}

\author{
Alejandro Parga Becerra, ${ }^{1,2}$ Aric F. Logsdon, ${ }^{4,5}$ William A. Banks, ${ }^{4,5}$ and Christopher B. Ransom ${ }^{1,2,3}$
}

https://doi.org/10.1523/ENEURO.0055-20.2021

${ }^{1}$ Epilepsy Center of Excellence, VA Puget Sound Health Care System, Seattle, WA 98108, ${ }^{2}$ Department of Neurology, University of Washington, Seattle, WA 98195, ${ }^{3}$ Department of Physiology and Biophysics, University of Washington, Seattle, WA 98195, ${ }^{4}$ Geriatric Research Education and Clinical Center, Veterans Affairs Puget Sound Health Care System, Seattle, WA 98108, and ${ }^{5}$ Division of Gerontology and Geriatric Medicine, Department of Medicine, University of Washington School of Medicine, Seattle, WA 98195

\begin{abstract}
Traumatic brain injury (TBI) causes cellular and molecular alterations that contribute to neuropsychiatric disease and epilepsy. GABAergic dysfunction figures prominently in the pathophysiology of TBI, yet the effects of TBI on tonic inhibition in hippocampus remain uncertain. We used a mouse model of severe TBI [controlled cortical impact $(\mathrm{CCl})$ ] to investigate GABAergic signaling in dentate gyrus granule cells (DGGCs). Basal tonic GABA currents were not affected by $\mathrm{CCl}$. However, tonic currents induced by the $\delta$ subunit-selective $\mathrm{GABA}_{\mathrm{A}}$ receptor agonist 4,5,6,7-tetrahydroisoxazolo[5,4-c]pyridin-3-ol (THIP; $10 \mu \mathrm{M}$ ) were reduced by 44\% in DGGCs ipsilateral to $\mathrm{CCl}$ (CCl-ipsi), but not in contralateral DGGCs. Reduced THIP currents were apparent one week after injury and persisted up to 15 weeks. The frequency of spontaneous IPSCs (sIPSCs) was reduced in CCIipsi cells, but the amplitude and kinetics of sIPSCs were unaffected. Immunohistochemical analysis showed reduced expression of $\mathrm{GABA}_{A}$ receptor $\delta$ subunits and $\mathrm{GABA}_{\mathrm{B}}$ receptor $\mathrm{B} 2$ subunits after $\mathrm{CCl}$, by $43 \%$ and $40 \%$, respectively. Activation of postsynaptic $\mathrm{GABA}_{\mathrm{B}}$ receptors caused a twofold increase in tonic currents, and this effect was markedly attenuated in CCl-ipsi cells (92\% reduction). GABA $A_{B}$ receptor-activated $\mathrm{K}^{+}$currents in DGGCs were also significantly reduced in CCl-ipsi cells, confirming a functional deficit of $\mathrm{GABA}_{B}$ receptors after CCl. Results indicate broad disruption of GABAergic signaling in DGGCs after CCl, with deficits in both phasic and tonic inhibition and $\mathrm{GABA}_{B}$ receptor function. These changes are predicted to disrupt operation of hippocampal networks and contribute to sequelae of severe TBI, including epilepsy.
\end{abstract}

Key words: epilepsy; GABAA receptor; GABAB receptor; hippocampus; TBI; tonic inhibition

\section{Significance Statement}

Traumatic brain injury (TBI) causes cellular and molecular changes that contribute to the clinical sequelae of TBI, including epilepsy, cognitive deficits, and mood disorders. Improved understanding of these cellular and molecular changes will inform therapeutic approaches to potentially disrupt epileptogenesis and treat symptoms. We investigated changes in GABAergic signaling of dentate gyrus granule cells (DGGCs) in a preclinical model of severe TBI [controlled cortical impact $(\mathrm{CCl})$ ] and identified early and persistent deficits in expression and function of both synaptic and extrasynaptic $G_{A B A}$ receptors and $G_{A B} A_{B}$ receptors. These broad changes in GABAergic signaling will alter function of DGGCs and are predicted to perturb hippocampal networks and contribute to epileptogenesis and cognitive deficits after TBI.

Received February 10, 2020; accepted January 12, 2021; First published January 29, 2021.

The authors declare no competing financial interests.
Author contributions: A.P.B. and C.B.R. designed research; A.P.B., A.F.L., and C.B.R. performed research; A.P.B. contributed unpublished reagents/ analytic tools; A.P.B. and C.B.R. analyzed data; A.P.B., A.F.L., W.A.B., and C. B.R. wrote the paper. 


\section{Introduction}

Traumatic brain injury (TBI) unleashes a cascade of cellular, molecular, and network changes that contribute to brain dysfunction after TBI, including cognitive deficits, $\mathrm{mood} / \mathrm{behavioral}$ disorders, and seizures (Perry et al., 2016). Severe TBI is a potent risk factor for epilepsy, up to $50 \%$ of individuals with a penetrating head injury develop posttraumatic epilepsy (PTE; Annegers et al., 1998; Garga and Lowenstein, 2006). Dysfunction of signaling by the inhibitory neurotransmitter GABA is believed to importantly contribute to epileptogenesis after TBI (Hunt et al., 2013; Guerriero et al., 2015).

GABA acts via distinct receptor subtypes to influence essentially every physiological and pathophysiological process in the brain. $\mathrm{GABA}_{\mathrm{A}}$ receptors containing $\gamma$ subunits cluster at synaptic connections and are transiently activated by vesicular GABA release to cause synaptic or phasic inhibition. In many areas of brain, high-affinity extrasynaptic $\mathrm{GABA}_{\mathrm{A}}$ receptors, containing either $\alpha 5$ or $\delta$ subunits, produce a tonic form of inhibition with distinct temporal and spatial characteristics compared with synaptic inhibition (Farrant and Nusser, 2005). In addition to activation by ambient GABA concentration, estimated to be in the range of 90-200 nм (Santhakumar et al., 2006), extrasynaptic $\mathrm{GABA}_{\mathrm{A}}$ receptors are believed to undergo agonist-independent, spontaneous channel openings that support tonic inhibition (Belelli et al., 2009; Patel et al., 2016). GABA also activates $\mathrm{GABA}_{B}$ receptors, which are G-protein-coupled receptors (GPCRs) present on both presynaptic and postsynaptic cells (Padgett and Slesinger, 2010). GABA $A_{B}$ receptors produce intracellular signal transduction and multiple effects, including reduction of cAMP/PKA activity, presynaptic inhibition of vesicular GABA release (Otis et al., 1993), and direct activation of $\mathrm{K}^{+}$channels (Isaacson et al., 1993).

Tonic inhibition is of particular interest in regard to TBI and PTE. Clinical experience and experimental data indicate that both excessive or deficient levels of tonic inhibition, caused by altered GABA transporter expression/ function or fluctuating neurosteroid levels, can exacerbate seizures and epilepsy (Koepp et al., 2005; Maguire et al., 2005; Cope et al., 2009). Additionally, tonic inhibition is increased after experimental stroke and pharmacological or genetic correction of this increase is associated with improved motor recovery (Clarkson et al., 2010). These results highlight the importance of appropriate regulation of tonic inhibition for normal brain function and to mitigate pathology. Tonic inhibition is regulated over short time

This work was supported by Merit Review I01BX002745-0 from the United States Department of Veterans Affairs (Biomedical Laboratory Research and Development) (to C.B.R.).

Acknowledgements: We thank Ning $\mathrm{Li}$ and Kristin Bullock for expert technical assistance.

Correspondence should be addressed to Christopher B. Ransom at cbr5@ uw.edu.

https://doi.org/10.1523/ENEURO.0055-20.2021

Copyright (C) 2021 Parga Becerra et al.

This is an open-access article distributed under the terms of the Creative Commons Attribution 4.0 International license, which permits unrestricted use, distribution and reproduction in any medium provided that the original work is properly attributed. frames (seconds to minutes) by vesicular GABA release, dynamic GABA transporter function, voltage-dependent properties of $\mathrm{GABA}_{A}$ receptors, and the actions of GPCRs (Glykys and Mody, 2007; Ransom et al., 2010, 2013; Connelly et al., 2013a). GABA B $_{\mathrm{B}}$ receptors potentiate tonic inhibition in several cell types, including dentate gyrus granule cells (DGGCs), cerebellar granule cells, interneurons, and thalamocortical neurons (Connelly et al., 2013b; Tao et al., 2013). This effect is mediated by postsynaptic $\mathrm{GABA}_{\mathrm{B}}$ receptors and $\delta$ subunit-containing extrasynaptic $\mathrm{GABA}_{A}$ receptors and provides a link between GABAergic signaling at distinct receptor subtypes. In DGGCs, $\mathrm{GABA}_{\mathrm{B}}$ receptors and $\delta$ subunit-containing extrasynaptic $\mathrm{GABA}_{A}$ receptors are both localized to perisynaptic/extrasynaptic portions of membranes (Kulik et al., 2003; Wei et al., 2003).

Published data supports GABAergic dysfunction after TBI. TBI causes a loss of GABAergic interneurons and reduced synaptic inhibition, which promotes hippocampal excitability (Huusko et al., 2015). Expression of many GABA and $\mathrm{GABA}_{B}$ receptor subunits in hippocampus are affected by $\mathrm{TBI}$ (mRNA and protein levels), including $\mathrm{GABA}_{\mathrm{A}}$ receptor subunits believed to be involved in tonic inhibition ( $\alpha 4$ and $\delta$ subunits; Kharlamov et al., 2011; Raible et al., 2012; Drexel et al., 2015). Tonic inhibition in DGGCs is also affected by experimental TBI but the reported results are variable with descriptions of enhanced, reduced, or unchanged tonic GABA currents after TBI (Mtchedlishvili et al., 2010; Pavlov et al., 2011; Gupta et al., 2012; Boychuk et al., 2016). This variability may relate in part to different TBI models, severity of injury, and timing and location of measurements after injury (i.e., ipsilateral vs contralateral hippocampus). Improved understanding of changes in GABAergic function after $\mathrm{TBI}$ is essential to critically assess mechanisms causing these changes and the role(s) of altered GABAergic signaling in epileptogenesis and the complex pathophysiology of TBI (Hunt et al., 2013; Glushakov et al., 2016).

We investigated the effects of controlled cortical impact (CCl) on GABAergic function of DGGCs in acute brain slices. Our results indicate early and persistent deficits in tonic inhibition after $\mathrm{CCl}$, effects that were restricted to ipsilateral hippocampus. In addition, the function of synaptic $\mathrm{GABA}_{\mathrm{A}}$ receptors and $\mathrm{GABA}_{B}$ receptors was reduced by $\mathrm{CCl}$. These results indicate that $\mathrm{GABAergic}$ signaling in DGGCs is broadly affected by $\mathrm{CCl}$. Altered function of $\mathrm{GABA}_{A}$ and $\mathrm{GABA}_{B}$ receptors are predicted to contribute to hyperexcitability of DGGCs/hippocampal networks and behavioral consequences of TBI.

\section{Materials and Methods}

\section{Animals}

Male C57 BL/6 mice were assigned to control or TBI groups. Electrophysiological and immunohistochemical assessments were performed at various time points after $\mathrm{CCl}$; different groups of animals were used for experiments at $3 \mathrm{~d}$, one week, two weeks, one month, and two months after injury. Animals were group housed and all protocols and procedures were approved by local IACUC. 


\section{CCI}

Mice aged five to six weeks were deeply anesthetized with inhaled isoflurane and placed in an electromagnetic cortical impactor system (ImpactOne device, Leica). Animal temperature was monitored and maintained during the procedure and post-surgery. A surgical window was opened over the scalp midline and a $3-\mathrm{mm}$ craniotomy was performed over the right parietal cortex without disrupting the dura. $\mathrm{CCl}$ group received head trauma with impacts delivered over $50 \mathrm{~ms}$ with a 2-mm rounded metal tip at a velocity of $3.5 \mathrm{~m} / \mathrm{s}$ to generate a 1-mm deformation in the cortical surface. After $\mathrm{CCl}$, the injury was sealed with dental cement and animals observed until recovery. Sham group received craniotomy but did not receive impact. Animal weights, behavior, and wounds were followed daily for the following $3 \mathrm{~d}$ to evaluate recovery; all animals survived this procedure, a single animal required euthanasia because of wound dehiscence.

\section{Brain slice preparation}

Animals were deeply anesthetized with $4 \%$ inhaled isoflurane then decapitated and brain dissected free from the skull. Brains were placed in ice-cold cutting solution with the following composition: $125 \mathrm{~mm} \mathrm{NaCl}, 3 \mathrm{~mm} \mathrm{KCl}$, $26 \mathrm{~mm} \mathrm{NaHCo}_{3}, 1.2 \mathrm{~mm} \mathrm{NaH}_{2} \mathrm{PO}_{4}, 0.5 \mathrm{~mm} \mathrm{CaCl}, 4 \mathrm{~mm}$ $\mathrm{MgCl}_{2}, 20 \mathrm{~mm}$ dextrose, and $1 \mathrm{~mm}$ kynurenic acid (osmolarity adjusted to $310 \pm 5 \mathrm{mOsm}$ ). Solutions were continuously gassed with $95 \% \mathrm{O}_{2} / 5 \% \mathrm{CO}_{2}$. Transverse slices of hippocampus (300- $\mu \mathrm{m}$ thickness) were cut with a vibratome (Leica, VT1200) in ice-cold cutting solution and then incubated in cutting solution for at least $1 \mathrm{~h}$ at room temperature before experiments.

\section{Electrophysiology}

Acute hippocampal brain slices were placed in a custom recording chamber with a volume of $\sim 3 \mathrm{ml}$ and continuously superfused at a rate of $2-3 \mathrm{ml} / \mathrm{min}$ with a bath solution containing the following: $134 \mathrm{~mm} \mathrm{NaCl}, 3 \mathrm{~mm} \mathrm{KCl}$, $26 \mathrm{~mm} \mathrm{NaHCO}, 1.4 \mathrm{~mm} \mathrm{NaH}{ }_{2} \mathrm{PO}_{4}, 2 \mathrm{~mm} \mathrm{CaCl}, 2 \mathrm{~mm}$ $\mathrm{MgCl}_{2}, 10 \mathrm{~mm}$ dextrose, and $1 \mathrm{~mm}$ kynurenic acid that was continuously gassed with $95 \% \mathrm{O}_{2} / 5 \% \mathrm{CO}_{2}$ to achieve a $\mathrm{pH}$ of 7.4. Bath solution osmolarity was adjusted to $295 \pm$ 5 mOsm. DGGCs were visualized with an upright microscope using DIC/infrared optics (Slice Scope Pro2000, Scientifica). Whole-cell patch clamp techniques were used to digitally record membrane currents using a Multiclamp 700B amplifier, Axon Digidata 1550b A-D converter, and pClamp10 software (Molecular Devices). Data were recorded at $5-10 \mathrm{kHz}$ and low-pass filtered at 1$2 \mathrm{kHz}$. Series resistance was monitored throughout experiments and compensated by $50 \%$, recordings with a series resistance $>20 \mathrm{M} \Omega$ or that had $>25 \%$ change in series resistance were not considered for analysis. Micropipettes were produced from thin-walled borosilicate glass with filament using a micropipette puller ( $\mathrm{P}-97$ Sutter). Pipettes had resistances of 5-9 $M \Omega$ when filled with a solution designed to isolate $\mathrm{GABA}_{\mathrm{A}}$ receptor currents that contained the following: $130 \mathrm{~mm} \mathrm{CsCl}, 10 \mathrm{~mm}$
EGTA, $10 \mathrm{~mm}$ HEPES, $10 \mathrm{~mm}$ QX-314 chloride, $4 \mathrm{~mm}$ $\mathrm{NaCl}, 0.5 \mathrm{~mm} \mathrm{Na}_{2} \mathrm{GTP}$, and $4 \mathrm{~mm} \mathrm{Mg-ATP}$, with adjusted $\mathrm{pH} 7.25$ with $\mathrm{CsOH}$. Osmolarity was adjusted to $280 \pm 5$ mOsm. When assessing $\mathrm{K}^{+}$currents a K-gluconate internal solution was used, containing the following: $125 \mathrm{~mm}$ K-gluconate, $10 \mathrm{~mm} \mathrm{KCl,} 1 \mathrm{~mm}$ EGTA, $10 \mathrm{~mm}$ HEPES, 4 $\mathrm{mm} \mathrm{NaCl}, 0.5 \mathrm{~mm} \mathrm{Na} \mathrm{K}_{2} \mathrm{GTP}$, and $4 \mathrm{~mm} \mathrm{Mg-ATP}$, with adjusted $\mathrm{pH} 7.25$ with $\mathrm{KOH}$. Kynurenic acid $(1 \mathrm{~mm}$ ) was included in bath solution to block ionotropic glutamate receptors for all patch clamp experiments. Membrane currents were measured at -70 or $-110 \mathrm{mV}$ (for $\mathrm{K}^{+}$currents). All experiments were performed at $32-34^{\circ} \mathrm{C}$.

\section{Drug administration}

Tonic GABA currents were measured by focal application of the $\mathrm{GABA}_{A}$ receptor antagonist bicuculline methiodide $(40 \mu \mathrm{M})$. Focal application was made by pressure ejection (Picospritzer III, Parker Hannifin) from a micropipette positioned above the tissue surface $\sim 50 \mu \mathrm{m}$ from the recorded cell and triggered by acquisition software, typically with 2-s duration pulses delivered every 2 min (5$10 \mathrm{psi}$ ). Effects from the small volume of bicuculline released during focal pressure ejection resolved within $60 \mathrm{~s}$. Other drugs were bath applied via bulk bath solution. Activation of $\mathrm{GABA}_{\mathrm{A}}$ receptors containing $\delta$ subunits was accomplished by application of the agonist 4,5,6,7-tetrahydroisoxazolo[5,4-c]pyridin-3-ol (THIP) at the following concentrations $0.3,1,3,10$, and $30 \mu \mathrm{M}$. GABA $A_{B}$ induced tonic current changes were assessed by application of $\mathrm{GABA}_{B}$ receptor agonist baclofen $(10 \mu \mathrm{M})$ and $\mathrm{GABA}_{\mathrm{B}}$ receptor antagonist CGP55845 (CGP; $10 \mu \mathrm{M})$. When assessing $\mathrm{GABA}_{B}$ receptor effect through $\mathrm{G}_{\mathrm{i} / \mathrm{o}}$, guanosine 5'-O-(2-thiodiphosphate) (GDP- $\beta$-s; $0.5 \mathrm{~mm}$ ) was used in the intracellular solution. Baclofen $(100 \mu \mathrm{M})$ was focallyapplied via pressure ejection for measurements of $G A B A_{B}$ receptor activated $\mathrm{K}^{+}$currents. Chemicals were purchased from Sigma and Tocris.

\section{Immunohistochemistry (IHC)}

Expression levels of $\mathrm{GABA}_{\mathrm{A}}$ receptor $\delta$ subunits and $\mathrm{GABA}_{B}$ receptor B2 subunits were assessed by $\mathrm{IHC}$ (Schneider Gasser et al., 2006). For immunohistochemical experiments, brains were fixed via cardiac perfusion (perfused with 20-ml PBS with 1000 units heparin and then 35- to 50-ml paraformaldehyde). Brains were fixed overnight in $10 \%$ formalin and then stored in $30 \%$ sucrose at $4^{\circ} \mathrm{C}$ until ready to cryosection. Brain slices ( $50 \mu \mathrm{m}$ thick) were cut with a cryostat and conditioned with $1 \mathrm{~m}$ PBS $(4 \times 20 \mathrm{~min})$. Tissue was permeabilized by incubating in PBS containing $0.25 \%$ Triton $X-100$ and $0.01 \%$ sodium acetate $(1 \mathrm{~h})$ and then rinsed with PBS containing $0.1 \%$ Triton X-100 (PBST; $3 \times 5 \mathrm{~min}$ ). Antigen retrieval for $\mathrm{GABA}_{\mathrm{A}}$ receptor $\delta$ subunits, NEUN, and GFAP was accomplished in PBS with $10 \mathrm{~mm}$ sodium citrate titrated to $\mathrm{pH} 6$ at $80^{\circ} \mathrm{C}(1 \times 30 \mathrm{~min})$ and slices were stored in blocking buffer overnight at $4{ }^{\circ} \mathrm{C}$ (PBS containing 2\% BSA, 2\% donkey serum, $0.25 \%$ Triton $\mathrm{X}-100)$. Antigen retrieval for $\mathrm{GABA}_{\mathrm{B}}$ receptor $\mathrm{B} 2$ subunits was accomplished in PBS with $0.05 \%$ Triton $\mathrm{X}-100$ at $50^{\circ} \mathrm{C}(30 \mathrm{~min})$ and then slices 
stored in blocking buffer (same as above but with $0.25 \%$ Triton X-100). Slices were incubated with primary antibodies overnight at $4^{\circ} \mathrm{C}$ [anti-GABA $A_{A} R$ Rb polyclonal diluted 1:3000 (R\&D Systems, catalog \#PPS090B); anti$\mathrm{GABA}_{\mathrm{B}} \mathrm{R} \beta_{2}$ goat polyclonal diluted to $5 \mu \mathrm{l} / \mathrm{ml}$ (R\&D Systems, catalog \#AF1188); anti-NEUN rabbit polyclonal diluted 1:2000 (Abcam, catalog \#ab104225); anti-GFAP chicken polyclonal diluted 1:2000 (Millipore, catalog \#AB5541)]. Primary antibody was washed with PBS containing $1 \%$ BSA, $0.25 \%$ Triton $X-100(4 \times 20 \mathrm{~min})$. Slices were incubated with secondary antibodies at room temperature for $2 \mathrm{~h}$ [Cy3 donkey anti-rabbit IgG (Jackson ImmunoResearch, catalog \#711-165-152) diluted 1:500 or Alexa Fluor 488 donkey anti-goat or anti-chicken IgG diluted 1:2000 (Jackson ImmunoResearch, catalog \#705545-147 and catalog \#703-545-155, respectively)]. Tissue was reconditioned by washing with PBST $(3 \times 5 \mathrm{~min})$ before staining with Fluoromount-G with DAPI (Invitrogen) and mounting on glass slides. Brain slices were imaged using an upright microscope (Eclipse Ni-E, Nikon). Tiled fluorescent images of the hippocampus were acquired using NIS-Elements software at $40 \times$ magnification using $390-\mathrm{nm}$ light for DAPI, $488 \mathrm{~nm}$ for Alexa Fluor and 560-nm light for Cy3.

\section{Analysis}

Electrophysiological recordings were analyzed with Clampfit (pClamp v10.6) and Origin (Microcal) software. Tonic GABA currents were measured as the change in mean holding current induced by the $\mathrm{GABA}_{\mathrm{A}}$ receptor antagonist bicuculline. Histograms of current were constructed at baseline and at peak of bicuculline response and fit with a Gaussian function using LevenbergMarquardt algorithm provided in Clampfit; the central moment of the Gaussian distribution defined mean holding current. Dose-response data were fit with a Hill equation of the form:

$$
I=I_{\max } *[T H I P]^{n} / E_{50}{ }^{n} *[T H I P]^{n}
$$

where $I_{\max }$ is peak current, $E_{50}$ is half-maximal effective concentration of THIP, and $\mathrm{n}$ is Hill coefficient. Spontaneous IPSCs (SIPSCs) were detected as negativegoing events and SIPSC parameters (frequency, amplitude, rise/decay times) were quantified using a template matching function in Clampfit. Immunohistochemical images were analyzed using ImageJ (v1.48d). Dentate gyrus granule cell layer (GCL), molecular layer (ML), and hilus were delineated on a DAPI-stained, paired image, and set as region of interest (ROI). The mean gray scale value of ROI was determined from individual sections (background-subtracted) and recorded as the intensity of antibody staining for $\mathrm{GABA}_{\mathrm{A}}$ receptor $\delta$ subunits and $\mathrm{GABA}_{\mathrm{B}}$ receptor $\mathrm{B} 2$ subunits. Group data are presented as mean and SEM, and statistical comparisons were made using either a one-way or two-way ANOVA and two-tailed, unpaired $t$ test included in software packages (Origin, Microsoft Excel), with a $p<0.05$ considered significant.

\section{Results}

\section{Histologic effects of $\mathrm{CCI}$ model}

$\mathrm{CCl}$ creates a direct and visible injury to the cortical surface but our focus is on CCl-related changes in the hippocampus, which is not directly affected by $\mathrm{CCl}$. To assess the effects of our $\mathrm{CCl}$ model on neuronal survival and neuroinflammation/astrogliosis in the hippocampus we performed immunohistochemical staining for the neuronal marker NEUN and GFAP at four weeks after injury (Fig. 1). Qualitative assessment of these immunohistochemical images indicate preservation of neurons targeted for whole-cell recordings in dentate gyrus, in hippocampus both contralateral and ipsilateral to $\mathrm{CCl}$. We did not quantify NEUN+ cell numbers but loss of neurons in area CA3 was visibly-appreciable in ipsilateral hippocampus in all slices examined from CCl-treated animals ( $n=4$ animals), this loss of CA3 neurons was not apparent in hippocampus contralateral to $\mathrm{CCl}$ (Fig. 1). GFAP staining was increased four weeks after $\mathrm{CCl}$ in the ipsilateral hippocampus compared with contralateral hippocampus. These results validate histologic alterations of hippocampus four weeks after $\mathrm{CCl}$ and indicate a strong laterality to these changes with evidence of persistent astrogliosis, a marker of neural injury and neuroinflammation (Colombo and Farina, 2016).

\section{CCl effects on tonic GABA currents in DGGCs}

We measured tonic GABA currents in DGGCs of acute hippocampal brain slices from control/sham-operated animals and animals exposed to $\mathrm{CCl}$. Recording conditions were designed to isolate $\mathrm{GABA}_{\mathrm{A}}$ receptor currents (CsCl pipette solution with $Q X-314$, extracellular kynurenic acid to block glutamate receptors). Tonic GABA currents were measured as the change in mean holding current at $-70 \mathrm{mV}$ produced by focal pressure ejection of the $\mathrm{GABA}_{\mathrm{A}}$ receptor antagonist bicuculline $(40 \mu \mathrm{M})$ from a micropipette positioned 30-50 $\mu \mathrm{m}$ from DGGC soma; mean holding current was determined as the center of Gaussian function fit to histograms of current data (Fig. 2A). Initial experiments were done on animals two weeks after $\mathrm{CCl}$ (i.e., 34-39 d old). Baseline tonic currents were similar between DGGCs from control animals and in DGGCs from both the contralateral and ipsilateral hippocampus of $\mathrm{CCl}$-treated animals (one-way ANOVA, $p=0.89 ; n=4-8$ cells; Fig. $2 A, B$ ). However, significant differences in tonic currents were observed in the presence of the GABA $\mathrm{A}_{\mathrm{A}}$ receptor $\delta$ subunit-selective agonist THIP (10 $\mu \mathrm{M}$; one-way ANOVA, $p<0.01$; Meera et al., 2011). CCl reduced THIP-induced tonic currents in ipsilateral hippocampus by $55 \%$ compared with control cells (control: $-81.6 \pm 12.2 \mathrm{pA}$ vs CCl-ipsi: $-36.4 \pm$ $9.0 \mathrm{pA}, n=4-8$ cells, $p<0.01$; Fig. $2 A, B)$. THIP-induced tonic currents were unaffected in contralateral hippocampus (CCl-contra: $-70.6 \pm 9.6 \mathrm{pA}, n=6$ cells, $p=0.55$; Fig. $2 A, C)$.

We next assessed the concentration dependence for THIP activation of tonic currents for control and CClipsi DGGCs. These data were collected 14-21d after $\mathrm{CCl}$ from two separate groups of $\mathrm{CCl}$-treated animals. Representative recordings of tonic currents from sham 
A

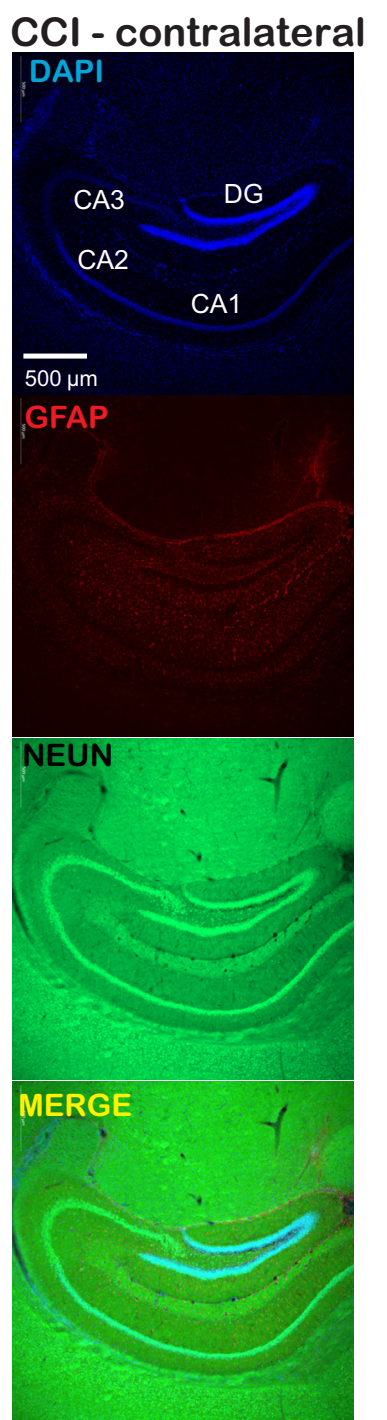

B
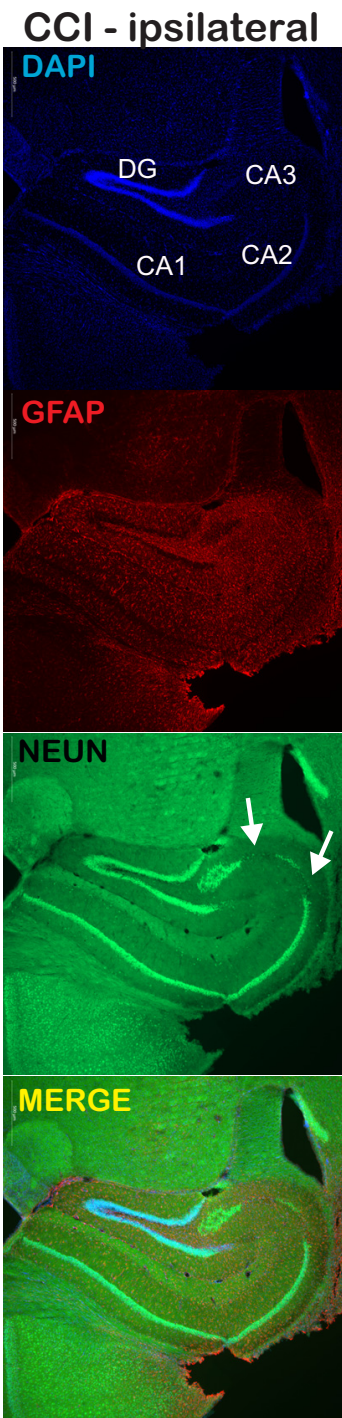

Figure 1. $\mathrm{CCl}$ produces persistent astrogliosis and loss of $\mathrm{CA} 3$ neurons that are restricted to the ipsilateral hippocampus. $\boldsymbol{A}$, Immunofluorescent images of contralateral hippocampus one month after CCI with DAPI (blue; nuclear), GFAP (red; astrocyte), NEUN (green; neuron), and merged images. Hippocampal subregions are labeled within the DAPI panel. $\boldsymbol{B}$, Immunofluorescent images from ipsilateral hippocampus after $\mathrm{CCl}$ showing DAPI, GFAP, NEUN, and merged images as in $\boldsymbol{A}$. Persistent astrogliosis after $\mathrm{CCl}$ is seen as increased GFAP staining, arrows indicate region of neuronal loss in the CA3 region within the NEUN panel. The astrogliosis and loss of CA3 neurons seen in ipsilateral hippocampus one month after $\mathrm{CCl}$ is absent in in the contralateral hippocampus; there is relative preservation of DGGCs targeted for our recordings, indicating these cells remain viable after $\mathrm{CCl}$. Scale bar $(500 \mu \mathrm{m})$ in upper left panel applies to all images.

and CCl-ipsi cells during bath application of THIP are illustrated in Figure $3 A, B$. At concentrations of $10 \mu \mathrm{M}$ or greater, THIP-induced tonic currents were significantly reduced in CCl-ipsi cells compared with control [10 $\mu \mathrm{M}$ THIP: $-100.3 \pm 9.9 \mathrm{pA}$ ( $n=6$ cells) vs $-66.0 \pm 13.8 \mathrm{pA}$ $(n=7)$ for sham/control and CCl-ipsi cells, respectively,

$p<0.05 ; 30 \mu \mathrm{M}$ THIP: $-150.3 \pm 29.2 \mathrm{pA}$ ( $n=6$ cells) vs $-71.4 \pm 17.7 \mathrm{pA}(n=7)$ for control and CCl-ipsi cells, respectively, $p<0.01$ ]. There was a trend for smaller tonic currents in CCl-ipsi cells with $3 \mu \mathrm{M}$ THIP, but this was not significant (control: $-59.0 \pm 9.3 \mathrm{pA}$ vs CCl-ipsi: $-46.3 \pm$ $9.4 \mathrm{pA}, n=6-8$ cells, respectively, $p=0.35$ ). The dose-response data were fit with a Hill equation with three degrees of freedom to yield estimated $\mathrm{EC}_{50}$ and Hill coefficient of 4.9 and $1.0 \mu \mathrm{m}$ for control cells and 2.5 and $0.94 \mu \mathrm{M}$ for CCl-ipsi cells, respectively (Fig. 3C). Fit comparison analysis generated an $F$ test value of $0.56(p=$ 0.66 ), indicating that these fits and associated parameters are not significantly different. These results indicate deficits in THIP-sensitive extrasynaptic GABA $_{A}$ receptors after $\mathrm{CCl}$, an effect that is manifest only at higher concentrations of THIP and is restricted to ipsilateral DGGCs ipsilateral to injury. The similar estimates of THIP affinity for tonic current activation in control and CCl-ipsi DGGCs suggests a pharmacologically-homogenous population of extrasynaptic receptors in both groups.

Using additional sets of experimental animals, we investigated the time course of changes in tonic currents following $\mathrm{CCl}$. To assess time-dependent changes after $\mathrm{CCl}$, individual tonic current measurements are plotted as a function of age and time after $\mathrm{CCl}$ and data were binned into groups less than four weeks or more four weeks after $\mathrm{CCl}$ for statistical comparison with age-matched controls (Fig. 4). There were no significant changes in baseline tonic currents after $\mathrm{CCl}$ in either group (average time after $\mathrm{CCl}$ of $14.6 \pm 1.8$ or $59.0 \pm 6.0 \mathrm{~d}$ ), or in ensemble analysis of measurements at all time points [two-way ANOVA indicated no effect of $\mathrm{CCl}(p=0.64)$ or time $(p=0.92)$; Fig. $4 A, B]$. Consistent with data obtained two to three weeks after $\mathrm{CCI}$, THIP-induced $(10 \mu \mathrm{M})$ tonic currents were significantly reduced in $\mathrm{CCl}$-ipsi cells within the first week of $\mathrm{CCl}$ and remained reduced at two months after $\mathrm{CCl}$; ensemble analysis of tonic currents in THIP $10 \mu \mathrm{m}$ at all time points for these groups of animals had mean values of $-105.7 \pm 4.8$ and $-58.7 \pm 4.6 \mathrm{pA}$ for control $(n=18)$ and CCI-ipsi $(n=24)$ cells, respectively (two-way ANOVA, $p<$ 0.01 for $\mathrm{CCl}$ effect, $p=0.76$ for effect of time after $\mathrm{CCl}$; Fig. 4E,F). Dose-response data obtained from animals two to three weeks after $\mathrm{CCl}$ (Fig. $3 \mathrm{C}$ ) showed a concentration dependence to $\mathrm{CCl}$-related changes in tonic current, with significant differences between control and CCl-ipsi cells seen only at THIP concentrations of $10 \mu \mathrm{M}$ or greater. However, tonic currents in the presence of 1 $\mu \mathrm{M}$ THIP that were recorded more than four weeks after $\mathrm{CCl}$ showed a significant reduction compared with agematched controls (average time after CCl of $69.6 \pm 3.6 \mathrm{~d}$; $p<0.01$; Fig. $4 C, D$ ). This effect was not seen for data from cells less than four weeks after $\mathrm{CCl}$ (average time after $\mathrm{CCl}$ of $14.6 \pm 1.9 \mathrm{~d}$ ), but analysis of data at all time points with two-way ANOVA showed a significant reduction of tonic currents in the presence of THIP $1 \mu \mathrm{m}$ in CCIipsi DGGCs (control: $-37.2 \pm 3.5 \mathrm{pA}, n=14$; CCl: $-22.6 \pm$ $2.4 \mathrm{pA}, n=23 ; p<0.01$ for $\mathrm{CCl}$ effect). This discrepancy could relate to inter-animal variability, inter-procedural variability in $\mathrm{CCl}$, or time-dependent changes in $\delta$ subunit expression after $\mathrm{CCl}$; our data do not suggest significant 
A

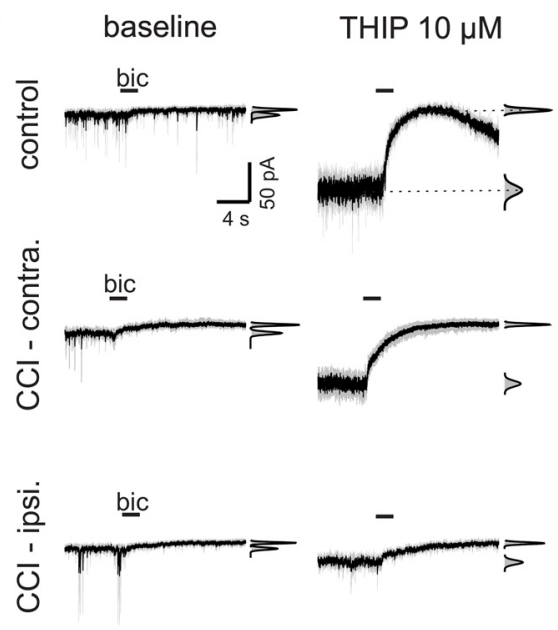

B

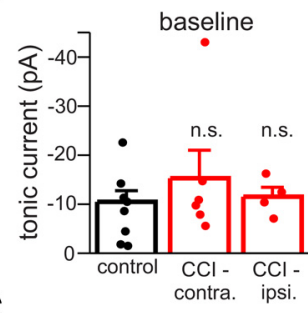

C

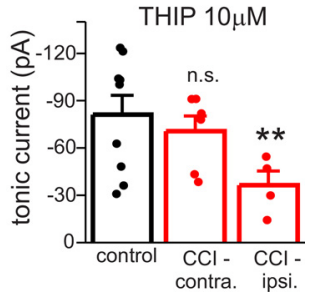

Figure 2. $\mathrm{CCl}$ reduces THIP-induced tonic currents, but not basal tonic currents, in ipsilateral DGGCs. $\boldsymbol{A}$, Membrane currents of DGGCs in response to focal application of the $\mathrm{GABA}_{\mathrm{A}}$ receptor antagonist bicuculline (Bic) application before and during exposure to THIP $(10 \mu \mathrm{M})$. CCl data recorded two weeks after injury. Illustrated currents are mean response (black line) of three focal applications of Bic overlaid with the individual responses to Bic in each cell (gray line). Insets to right of each trace represent all-points histogram and Gaussian fits used to measure mean holding current before and after Bic application; tonic current amplitude is defined as difference in mean holding current produced by Bic. Horizontal bars represent period of drug application in this and subsequent figures. Holding potential was $-70 \mathrm{mV}$. B, Mean baseline tonic current ( \pm SEM) of DGGCs in control, CCl-contra, or CCl-ipsi slices. Baseline tonic currents were unaffected by $\mathrm{CCl}$ two weeks after injury. Solid circles represent data from individual cells in this and subsequent figures. C, Mean THIP-induced tonic current of DGGCs in control, CCl-contra, or CCl-ipsi slices. CCI significantly reduced amplitude of THIP-induced currents in CCl-ipsi cells only; ${ }^{* *} p<0.01$, n.s., not significant.
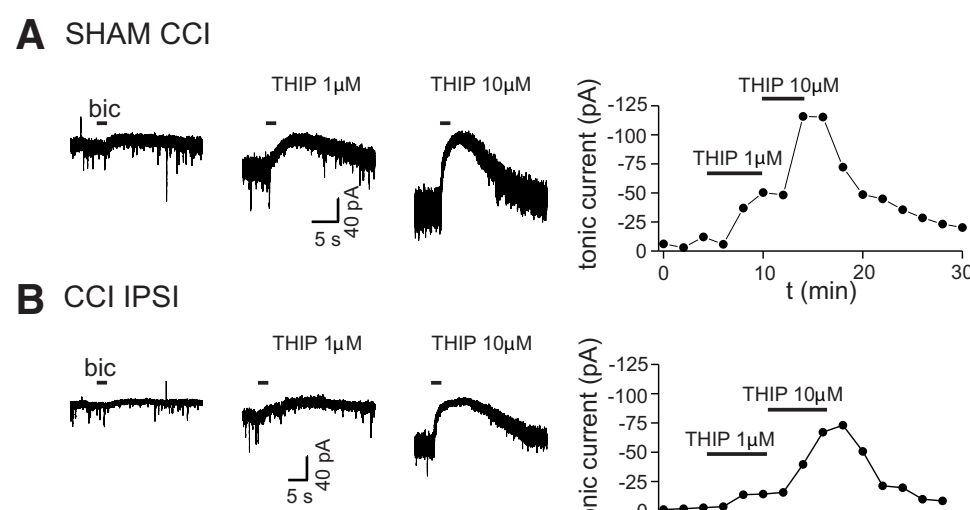

C

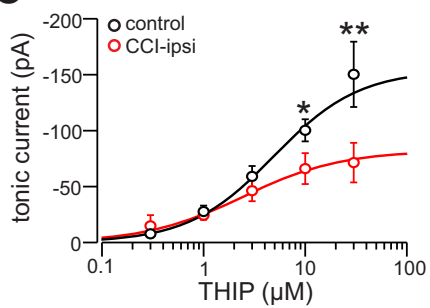

D
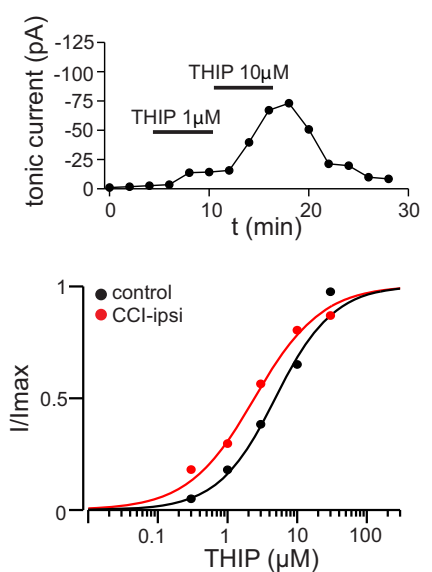

Figure 3. Dose dependence of $\mathrm{CCl}$ effects on THIP-induced tonic currents. A, Membrane currents from a sham-treated cell before and during bath application of increasing concentrations of THIP. Right hand panel shows time course of tonic current change for this experiment. $\boldsymbol{B}$, Membrane currents from a CCl-ipsi cell before and during bath application of THIP, right hand panel shows time course of current change for this experiment. C, Dose-response relationship for THIP-activation of tonic currents in control and CCI-ipsi DGGCs. Data points represent mean \pm SEM. CCl reduced current amplitudes with THIP concentrations $>3 \mu \mathrm{m}$. Solid line is a Hill equation fit to data, the estimated $\mathrm{EC}_{50}$ was 4.9 and $2.5 \mu \mathrm{m}$ for control and CCl-ipsi cells, respectively. $\boldsymbol{D}$, Normalized dose response data from $\boldsymbol{C}$. Data and fitted curves were normalized to maximum value $\left(I_{\max }\right)$ for these fits to better illustrate the similar $\mathrm{EC}_{50}$ values. Error bars are omitted for clarity. ${ }^{*} p<0.05,{ }^{* *} p<0.01$. 
A

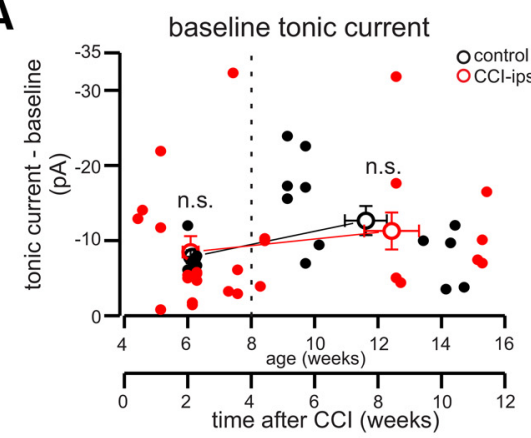

C

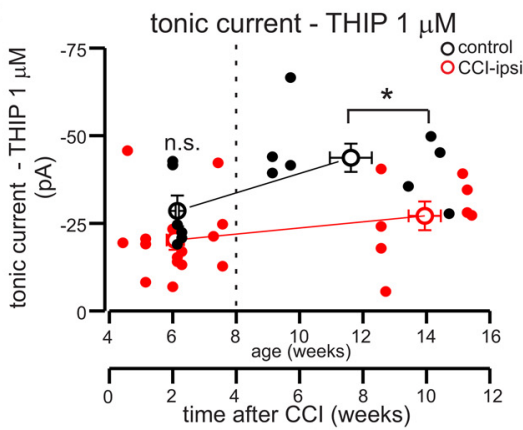

E

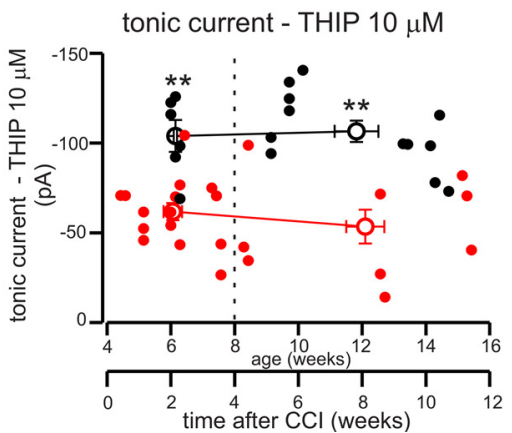

B all time points - baseline

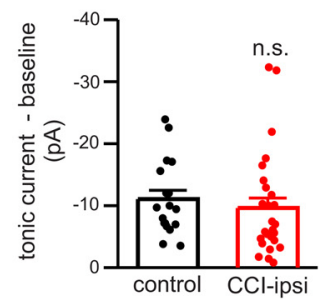

D all time points - THIP $1 \mu \mathrm{M}$

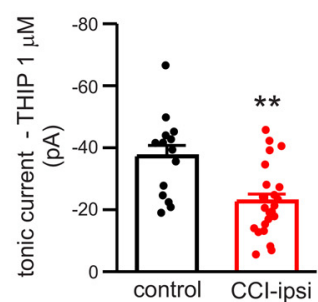

$\mathbf{F}$ all time points - THIP $10 \mu \mathrm{M}$

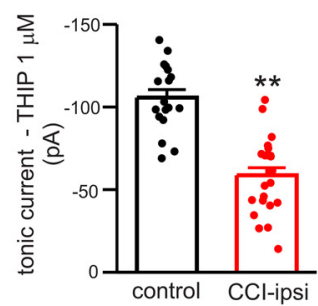

Figure 4. Time dependence of changes in baseline and THIP-induced tonic currents after $\mathrm{CCl}$. $\boldsymbol{A}$, Baseline tonic current amplitude as a function of age and time after $\mathrm{CCl}$ for control and CCl-ipsi cells. Open circles are mean $\pm \mathrm{SEM}$ of binned data; data binned into groups of cells less than four weeks after $\mathrm{CCl}$ or more than four weeks after $\mathrm{CCl}$ (dashed line). Solid circles are measurements from individual control (black) or CCl-ipsi (red) cells. B, Mean \pm SEM of basal tonic currents at all time points. $\boldsymbol{C}$, Time course of THIP-induced (1 $\mu \mathrm{M})$ tonic currents after $\mathrm{CCl}$ for $\mathrm{CCl}$-ipsi cells and age-matched controls. $\boldsymbol{D}$, Mean \pm SEM of tonic currents with $1 \mu \mathrm{m}$ THIP at all time points. Tonic currents with $1 \mu \mathrm{M}$ THIP were not significantly different compared with control less than four weeks after injury but significant differences were seen in cells more than four weeks after $\mathrm{CCl}$ and in ensemble analysis of all time points. $\boldsymbol{E}$, Time course of tonic currents induced by THIP $(10 \mu \mathrm{M})$ after $\mathrm{CCl}$ for control and CCl-ipsi cells. n.s., not significant; ${ }^{*} p<0.05,{ }^{* *} p<0.01$.

effect of time after CCl (two-way ANOVA, $p=0.28$ ). $\mathrm{CCl}$ data presented in Figure 4 was obtained from a total of 26 cells in slices from 16 animals from four separate groups of CCl-treated mice.

These results indicate that alterations in THIP-sensitive, extrasynaptic $\mathrm{GABA}_{A}$ receptors occur within one week of injury and persist for at least eight weeks. $\mathrm{CCl}$ data presented in Figure 4 was obtained from a total of 26 cells in slices from 16 animals from four separate groups of $\mathrm{CCl}$ treated mice.

\section{CCl affects synaptic input to DGGCs}

We examined the properties of sIPSCs in control and CCl-ipsi DGGCs (Fig. 5). DGGCs from $\mathrm{CCl}$ animals displayed a significant reduction in frequency of sIPSCs compared with control animals $(59 \%$ reduction on average, control: $0.99 \pm 0.1 \mathrm{~Hz}$ vs CCl-ipsi: $0.41 \pm 0.07 \mathrm{~Hz}$, $n=15-18$ cells for each condition; one-way ANOVA, $p<0.01$; Fig. $5 A, B, D)$. However, there were no significant differences of sIPSC amplitude, rise time, or decay time constant in CCl-ipsilateral DGGCs compared with control cells (Fig. $5 C, D$ ). The alteration in sIPSC frequency, but not the properties of sIPSCs themselves, seen after $\mathrm{CCl}$ is most consistent with a presynaptic effect because of either a loss of GABAergic interneurons or an alteration of release probability (Hunt et al., 2013; Huusko et al., 2015). Our data does not distinguish between these possibilities nor other potential mechanisms. These results indicate that spontaneous synaptic inhibition of DGGCs is 
A

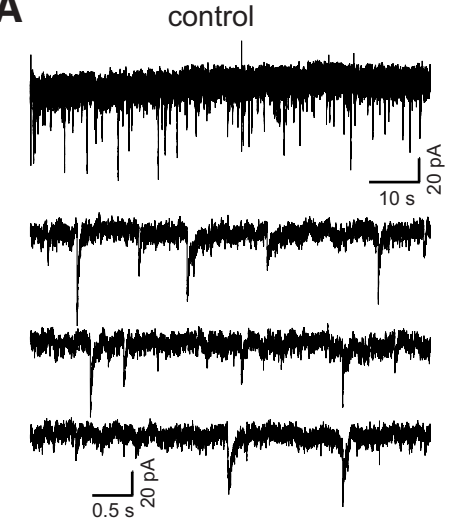

B $\mathrm{CCl}$ - ipsilateral
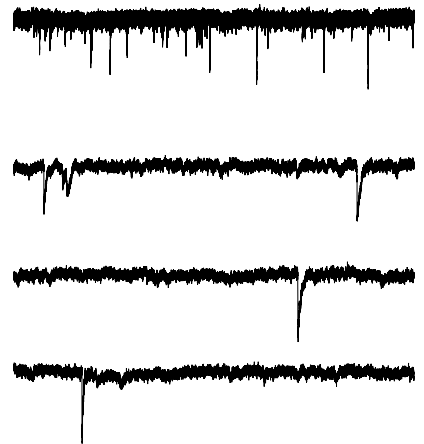
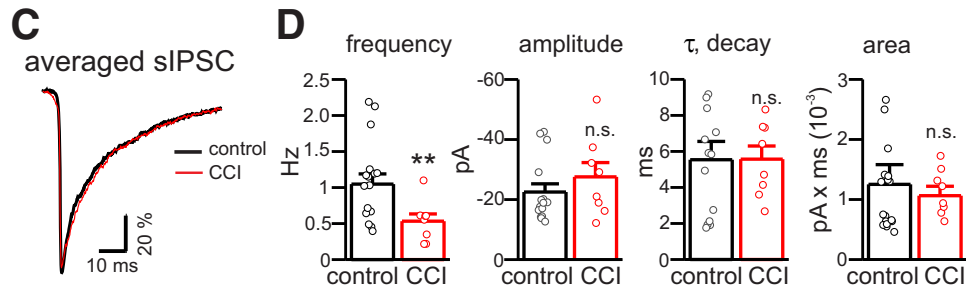

Figure 5. $\mathrm{CCl}$ reduces frequency, but not amplitude or kinetics, of sIPSCs in CCI-ipsilateral cells. $\boldsymbol{A}$, Membrane currents from control and CCl-ipsi DGGCs (2 min of gap-free recording at $-70 \mathrm{mV}$ ). $\boldsymbol{B}$, Data from $\boldsymbol{A}$ on expanded timescale. Reduced frequency of sIPSCs in CCl-ipsi cells is visibly apparent two weeks after CCI. $\boldsymbol{C}$, Average sIPSC from control and CCI-ipsi DGGCs. Average sIPSCs were normalized to allow comparison of time course and decay kinetics, which were indistinguishable between control and CCI-ipsi cells. $\boldsymbol{D}$, Mean ( \pm SEM) for sIPSC parameters in control and $\mathrm{CCl}$ cells. CCI significantly decreased sIPSC frequency by $59 \%$, but sIPSC amplitude, rise time, decay time constant, and total charge transfer were not significantly affected. Circles represent data from individual cells of control (black) or CCl-treated (red) animals. n.s., not significant. ${ }^{* *} p<0.01$.

reduced after $\mathrm{CCl}$, consistent with prior studies (Pavlov et al., 2011; Boychuk et al., 2016).

\section{Immunohistochemical analysis of GABA receptor expression after $\mathbf{C C l}$}

The reduction of THIP-induced tonic currents after $\mathrm{CCl}$ suggests reduced expression of $\mathrm{GABA}_{\mathrm{A}}$ receptor $\delta$ subunits in dentate gyrus after $\mathrm{CCl}$. We assessed expression of $\mathrm{GABA}_{\mathrm{A}}$ receptor $\delta$ subunits by quantifying immunofluorescence in dentate gyrus of control and $\mathrm{CCl}$-treated hippocampus (two weeks after CCl; Schneider Gasser et al., 2006). The IHC confirmed $\delta$ subunit expression in cell body layer, ML, and hilar region of dentate gyrus (Fig. 6A). Quantification of signal intensity from gray-scale images (normalized to ROI area) showed a significant reduction of staining density for $\delta$ subunits in all regions of the dentate gyrus after CCl (GCL, ML, and hilus). On average, CCl caused a $40 \%$ reduction in intensity of $\delta$ subunit staining across the entire dentate gyrus $(n=18-19$ slices from three animals under each condition, $p<0.01$; Fig. $6 B$ ). $\delta$ Subunit staining was reduced in GCL, ML, and hilus by $40 \%, 39 \%$, and $49 \%$, respectively. The decrease in $\delta$ subunit staining is quantitatively similar to the $39-44 \%$ reduction in THIP-induced tonic currents aforementioned (i.e., Fig. $4 D, F$ ).

In addition to effects on receptors involved in tonic and phasic inhibition, $\mathrm{CCl}$ could also alter signaling via metabotropic $\mathrm{GABA}_{B}$ receptors that secondarily affect tonic inhibition (Tao et al., 2013). We investigated the effects of $\mathrm{CCl}$ on expression of $\mathrm{GABA}_{\mathrm{B}}$ receptor $\mathrm{B} 2$ subunits in dentate gyrus. Staining for $\mathrm{GABA}_{B}$ receptors was present in cell bodies, ML, and hilar region (Fig. $6 C$ ). Quantification of staining intensity for $G_{A B A_{B}} B 2$ subunits showed significant reduction in ipsilateral dentate gyrus after $\mathrm{CCl}$. On average, $\mathrm{CCl}$ caused a $38 \%$ reduction in staining intensity for $\mathrm{GABA}_{\mathrm{B}}$ B2 subunits across the entire dentate gyrus $(n=15-19$ slices from three animals under each condition, $p<0.05$; Fig. $6 D$ ). $\mathrm{GABA}_{\mathrm{B}}$ B2 subunit staining was significantly reduced in GCL and hilus by $58 \%$ and $46 \%$, respectively $(p<0.05)$.

Our immunohistochemical results indicating reduced expression of $G_{A B A}$ and $G A B A_{B}$ receptor subunits after $\mathrm{CCl}$ are consistent with prior studies using western blots and in situ hybridization (Raible et al., 2012; Drexel et al., 2015). These supportive results taken together with our electrophysiology data indicate that $\mathrm{CCl}$ produces broad dysfunction of GABAergic signaling in DGGCs, with altered function of receptors involved in tonic inhibition, fast and slow synaptic inhibition, and both presynaptic and postsynaptic modulatory actions.

\section{$\mathrm{GABA}_{B}$ receptor modulation of tonic currents is attenuated after $\mathrm{CCI}$}

The reduction of $\mathrm{GABA}_{B}$ receptor expression after $\mathrm{CCl}$ led us to hypothesize that modulation of tonic currents produced by $\mathrm{GABA}_{\mathrm{B}}$ receptor activation would be attenuated after injury (Tao et al., 2013). To test this, we evaluated the modulation of tonic GABA currents by the $\mathrm{GABA}_{B}$ receptor agonist baclofen in control and CCl tissue. These experiments were done in the presence of 
A

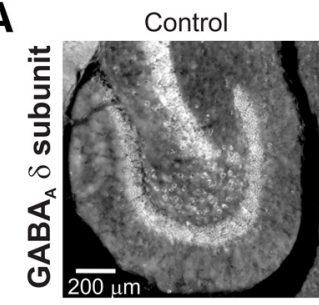

C

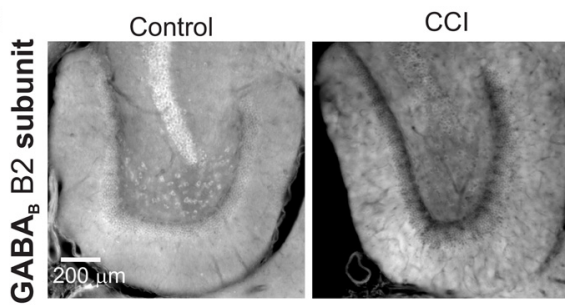

B
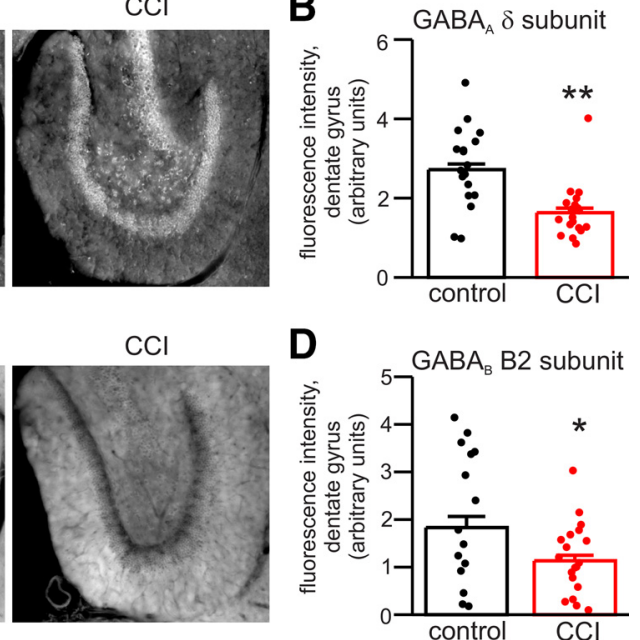

Figure 6. Immunohistochemical analysis of $\mathrm{CCl}$ effects on expression of $\mathrm{GABA}_{\mathrm{A}}$ receptor $\delta$ subunits and $\mathrm{GABA}$ receptor $\mathrm{B} 2$ subunits in dentate gyrus. $\boldsymbol{A}$, Immunofluorescent micrographs of staining for $\mathrm{GABA}_{\mathrm{A}}$ receptor $\delta$ subunit in dentate gyrus of control and $\mathrm{CCl}$-ipsi slices. Gray scale images used for quantification are illustrated. B, Mean signal intensity (arbitrary units) for GABA receptor $\delta$ subunit staining of control and CCl-ipsi dentate gyrus. Quantification of signal intensity was normalized to area of ROls, illustrated data points are the average of area-specific intensity of ROI for entire dentate gyrus (solid circles represent data from individual slices). $\mathrm{CCl}$ significantly reduced staining intensity for $\mathrm{GABA}_{\mathrm{A}}$ receptor $\delta$ subunit in dentate gyrus. $\boldsymbol{C}$, Immunofluorescent micrographs of $\mathrm{GABA}_{B}$ receptor $\mathrm{B} 2$ subunit staining in dentate gyrus of control and $\mathrm{CCl}$-ipsi slices. $\boldsymbol{D}$, Mean signal intensity of GABA $\mathrm{B}_{\mathrm{B}}$ receptor $\mathrm{B} 2$ subunit staining. $\mathrm{CCl}$ significantly reduced intensity of $\mathrm{GABA}_{\mathrm{A}}$ receptor $\delta$ subunit staining in dentate gyrus. ${ }^{*} p<0.005$, ${ }^{* *} p<0.01$.

$1 \mu \mathrm{M}$ THIP to provide larger, more stable tonic currents while assessing modulation and to constrain our measurements to $\delta$ subunit-containing $\mathrm{GABA}_{\mathrm{A}}$ receptors. In control tissue, tonic currents were increased during bath application of baclofen (BAC, $10 \mu \mathrm{M})$, an effect that developed within minutes (baseline: $-23.6 \pm 5 \mathrm{pA}$ vs BAC: $-76.0 \pm 33 \mathrm{pA}, n=11, p=0.01$; Fig. $7 A, B)$. The GABA $\mathrm{B}$ receptor antagonist CGP $(10 \mu \mathrm{M})$ partially inhibited the response to baclofen, but significantly reduced the change in tonic current induced by baclofen compared with control (tonic current change with BAC: $-52.4 \pm 28 \mathrm{pA}$ vs tonic current change with CGP + BAC: $-8.1 \pm 5 \mathrm{pA}$, $n=9-11$ cells, $p<0.05$; Fig. 7B). Intracellular solutions containing $0.5 \mathrm{~mm}$ GDP- $\beta$-S, a GTP analog that inhibits the function of GPCRs (Takahashi et al., 1998; Patenaude et al., 2003; Huang et al., 2015), prevented enhancement of tonic currents during BAC application (Fig. 7B). These results indicate that activation of postsynaptic $\mathrm{GABA}_{\mathrm{B}}$ receptors enhance tonic currents mediated by $\delta$ subunitcontaining $\mathrm{GABA}_{\mathrm{A}}$ receptors.
A
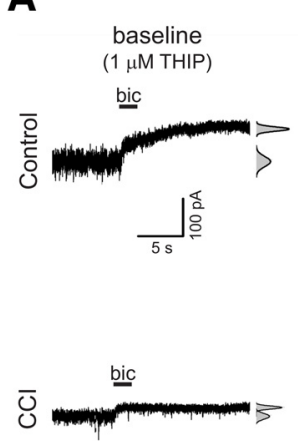

B

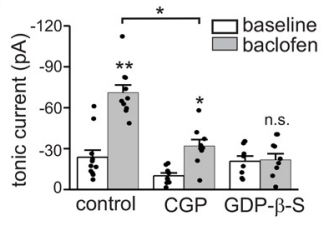

c

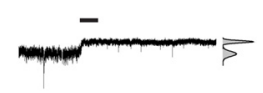

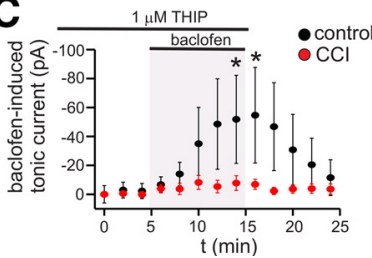

Figure 7. Enhancement of tonic currents by postsynaptic $\mathrm{GABA}_{\mathrm{B}}$ receptors is attenuated after $\mathrm{CCl}$. $\boldsymbol{A}$, Membrane currents in response to bicuculline (bic) application in control and CCl-ipsi cells before (left panel traces) and during baclofen (10 $\mu \mathrm{M})$ application (right-panel traces). All data in this figure were recorded in the presence of low concentrations of THIP (1 $\mu \mathrm{M})$. B, Mean tonic current

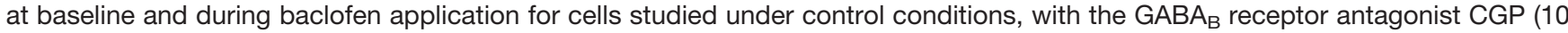
$\mu \mathrm{M})$, or with intracellular GDP- $\beta-\mathrm{S}(0.5 \mathrm{~mm})$. Baclofen significantly increased tonic currents under control conditions. This effect was partially blocked by CGP, with significant reduction in magnitude of tonic current change compared with control. Disruption of Gprotein signaling with intracellular GDP- $\beta$-S prevented baclofen-induced tonic current increases. $\boldsymbol{C}$, Time course of tonic current change during baclofen application (baclofen-induced tonic current) in control and CCl-ipsi cells; n.s., not significant. ${ }^{\star} p<0.05$, ${ }^{\star \star} p<0.01$. 


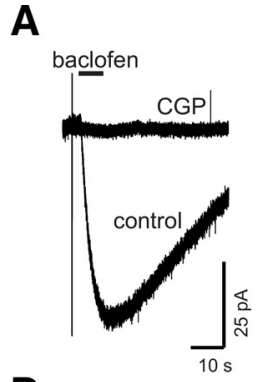

B

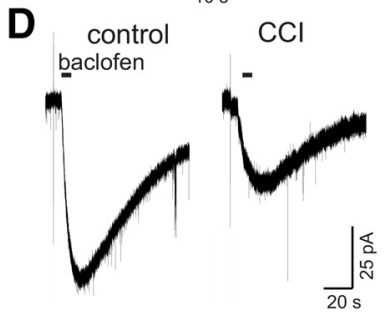

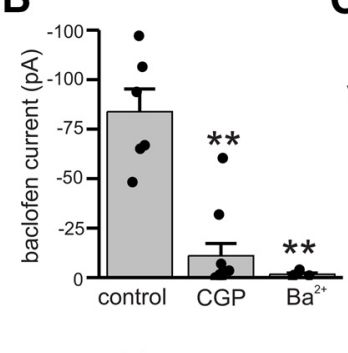

C

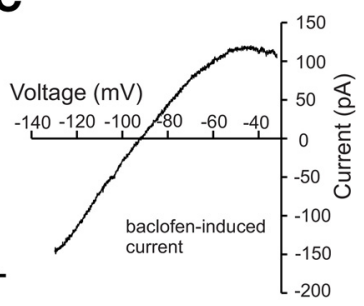

F 2 months after $\mathrm{CCl}$

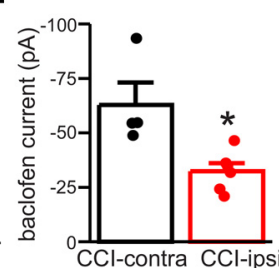

Figure 8. $\mathrm{CCl}$ reduces $\mathrm{GABA}_{B}$ receptor activated $\mathrm{K}^{+}$currents. $\boldsymbol{A}$, Membrane currents in response to focal application of baclofen (100 $\mu \mathrm{M}, 5-\mathrm{s}$ application) before and during bath application of CGP $(10 \mu \mathrm{M})$. Currents were measured with $\mathrm{K}^{+}$-gluconate pipette solution at $-110 \mathrm{mV}$. $\boldsymbol{B}$, Mean current induced by baclofen under control conditions, with GGP, or the $\mathrm{K}^{+}$channel blocker $\mathrm{Ba}^{2+}(100$ $\mu \mathrm{M})$. CGP and $\mathrm{Ba}^{2+}$ inhibited baclofen-induced currents by $74 \%$ and $82 \%$, respectively. $C$, Current-voltage plot of ramp current induced by baclofen (subtracted). Baclofen-induced ramp currents were inwardly-rectifying and the illustrated current reversed direction at $-90 \mathrm{mV}$. D, Baclofen-evoked $\mathrm{K}^{+}$currents in control and CCl-ipsi DGGCs. $E$, Mean $\mathrm{GABA}_{\mathrm{B}}$ receptor activated $\mathrm{K}^{+}$current in control and $\mathrm{CCl}$-ipsi cells. On average, $\mathrm{CCl}$ reduced $\mathrm{GABA}_{\mathrm{B}}$ receptor-activated $\mathrm{K}^{+}$currents by $66 \%$. $\boldsymbol{F}$, Mean $\mathrm{GABA}_{\mathrm{B}}$ receptor activated $\mathrm{K}^{+}$current in $\mathrm{CCl}$-contra and CCl-ipsi DGGCs two months after $\mathrm{CCl}$. GABA $\mathrm{B}_{\mathrm{B}}$ receptor activated $\mathrm{K}^{+}$currents are reduced in CCl-ipsi cells by $48 \%$ compared with CCl-contra cells two months after injury. ${ }^{*} p<0.05,{ }^{\star *} p<0.01$.

We next examined baclofen modulation of tonic currents in DGGCs two weeks after $\mathrm{CCl}$. Tonic current enhancement by $\mathrm{GABA}_{\mathrm{B}}$ receptor activation was significantly attenuated in CCl-ipsi DGGCs compared with control (Fig. $7 A, C)$. On average, THIP-induced tonic currents of CCl-ipsi DGGCs were $-15.4 \pm 5.8 \mathrm{pA}$ at baseline and increased to $-19.6 \pm 4.8 \mathrm{pA}$ during baclofen application ( $n=8, p=0.2$; Fig. $7 C$ ). The increase in tonic current amplitude produced by baclofen in CCl-ipsi DGGCs was, on average, only $8 \%$ of that seen in control cells. These findings demonstrate that $\mathrm{CCl}$ impairs modulation of tonic inhibition by $\mathrm{GABA}_{\mathrm{B}}$ receptors.

\section{$\mathrm{GABA}_{\mathrm{B}}$ receptor activated $\mathrm{K}^{+}$currents are reduced after $\mathbf{C C l}$}

Results presented above indicate that $\mathrm{CCl}$ reduces $\mathrm{GABA}_{\mathrm{B}}$ receptor expression and function. To further evaluate functional changes in postsynaptic $\mathrm{GABA}_{B}$ receptors after $\mathrm{CCl}$, we directly measured $\mathrm{K}^{+}$currents in response to focal application of baclofen $(100 \mu \mathrm{M})$. These experiments were done with $\mathrm{K}^{+}$-gluconate pipette solution and cells were held at $-110 \mathrm{mV}$ during baclofen application to provide sufficient driving force for $\mathrm{K}^{+}$currents. In control DGGCs, baclofen-induced inward currents were sensitive to the GABA $A_{B}$ receptor antagonist CGP $(10 \mu \mathrm{M})$ and the inwardly-rectifying $\mathrm{K}^{+}$channel blocker $\mathrm{Ba}^{2+}(100 \mu \mathrm{m} ; n=5-$ 6 cells for both CGP and $\mathrm{Ba}^{2+}, p<0.01$ for both; Fig. $8 A, B)$. Additionally, we recorded currents in response to ramp voltage commands (from -140 to $-30 \mathrm{mV}$ ) before and during baclofen application; subtraction of these records yielded the baclofen-induced ramp current. These ramp currents were inwardly-rectifying and had a reversal potential near the equilibrium potential for $\mathrm{K}^{+}$ions (mean reversal potential of $-81.2 \pm 3 \mathrm{mV}$, range $=-76$ to -92 $\mathrm{mV}, n=4$; Fig. $8 C$ ). These data indicate that focal application of baclofen stimulated $\mathrm{GABA}_{\mathrm{B}}$ receptor-activated $\mathrm{K}^{+}$ channels.

Baclofen-induced $\mathrm{K}^{+}$currents were significantly reduced in CCl-ipsi DGGCs two weeks after CCl. On average, GABA ${ }_{B}$-activated $\mathrm{K}^{+}$currents in CCl-ipsi cells were reduced by $55 \%$ compared with control $(n=6-8$ cells, $p$ $<0.01$ ) and by $51 \%$ compared with the $\mathrm{CCl}$-contra cells (Fig. 8D,E). To assess whether the changes in $\mathrm{GABA}_{\mathrm{B}}$ activation of $\mathrm{K}^{+}$currents persisted beyond two weeks after injury a subset of animals was studied two months after $\mathrm{CCl}$. At this later time point, the baclofen-induced $\mathrm{K}^{+}$currents of $\mathrm{CCl}$-ipsi cells were significantly reduced compared with CCl-contra cells $(n=4-6, p<0.01$; Fig. 8F). These data indicate that $\mathrm{CCl}$ causes early and persistent functional deficits of $G A B A_{B}$ receptors, including activation of postsynaptic $\mathrm{K}^{+}$channels and altered intracellular signaling involved in modulation of tonic GABA currents.

\section{Discussion}

Our results provide evidence for broad disruption of GABAergic signaling in DGGCs in a model of severe TBI (CCl). Our data indicate that $\mathrm{CCl}$ produces downregulation of $\delta$ subunit-containing $\mathrm{GABA}_{\mathrm{A}}$ receptors, reduction of spontaneous synaptic input, and functional impairments in $G_{A B A}$ receptor signaling. Immunolabeling of neurons (NEUN) after $\mathrm{CCl}$ indicates cell loss in area CA3 with relative preservation of DGGCs targeted for recordings, and suggests that observed physiological changes are not a consequence of simple neurodegeneration and 
cell death but are a manifestation of surviving neurons. These factors are predicted to dramatically alter inhibitory signaling and hippocampal function with implications for the cognitive and behavioral consequences of TBI, as well as epileptogenesis and recurrent seizures in chronic epilepsy.

\section{TBI and tonic inhibition}

$\mathrm{CCl}$ did not affect baseline tonic currents because of endogenous GABA in DGGCs at all time points studied, consistent with prior studies that have measured basal tonic currents one to six months after experimental TBI [CCl or severe fluid percussion injury (FPI); Pavlov et al., 2011; Boychuk et al., 2016; but see Mtchedlishvili et al., 2010; Gupta et al., 2012]. However, tonic currents induced by the $\delta$ subunit selective agonist THIP were significantly reduced in DGGCs by one week after $\mathrm{CCl}$ and remained reduced up to two months after injury. This effect was restricted to CCl-ipsi cells, suggesting factors that alter properties of DGGCs are limited to the injured hemisphere. At two weeks after $\mathrm{CCl}$, our data identified a concentration dependence to this effect and significant reduction of THIP-induced tonic currents was only seen at concentrations $>3 \mu \mathrm{M}$. The estimated THIP affinity was similar between control and CCl-ipsi DGGCs $\left(\mathrm{EC}_{50}\right.$ of 4.9 vs $2.5 \mu \mathrm{m}$ for control and CCl-ipsi, respectively). Our affinity estimates compare well to data on THIP sensitivity of recombinant extrasynaptic $\mathrm{GABA}_{\mathrm{A}}$ receptors in HEK cells $(\alpha 4 \beta 3 \delta$ and $\alpha 6 \beta 3 \delta)$, these studies report $\mathrm{EC}_{50}$ values ranging from 2.9 to $13 \mu \mathrm{m}$ (Meera et al., 2011; Mortensen et al., 2010). For comparison, the $\mathrm{EC}_{50}$ for THIP activation of synaptic type $\mathrm{GABA}_{A}$ receptors containing $\gamma 2$ subunits is in the range of $69-423 \mu \mathrm{m}$ and binary receptors composed of only $\alpha \beta$ subunits have an intermediate THIP sensitivity. These considerations indicate that the concentrations of THIP we used provided some selectivity for high-affinity extrasynaptic $\mathrm{GABA}_{\mathrm{A}}$ receptors, which potentially include a mixture of receptors with both $\alpha \beta \delta$ and $\alpha \beta$ subunit composition (Mortensen and Smart, 2006; Meera et al., 2011). Thus, $\mathrm{CCl}$ causes early and persistent alterations of extrasynaptic $\mathrm{GABA}_{A}$ receptor expression and function, a conclusion supported by immunohistochemical analysis showing reduced immunofluorescence of $\delta$ subunits after $\mathrm{CCl}$.

Measurements of THIP-induced currents in DGGCs after experimental TBI have provided variable results, with descriptions of either increased THIP-induced currents (Mtchedlishvili et al., 2010; Gupta et al., 2012), decreased THIP-induced currents (Boychuk et al., 2016), or no change in THIP-induced currents (Pavlov et al., 2011). These studies all used THIP concentrations of $1-3 \mu \mathrm{m}$; in the light of our data showing a concentration dependence for detecting altered THIP currents after $\mathrm{CCl}$, it is compelling to speculate that use of higher concentrations of THIP may have revealed additional or more consistent alterations of tonic currents after $\mathrm{CCl}$. Technical factors relating to degree of experimental brain injury, timing of measurements after injury, hemisphere under study (ipsilateral vs contralateral), and even factors related to animal strains could account for some of the reported variability. The core finding that $\mathrm{CCl}$ reduces THIP currents in ipsilateral DGGCs was observed in six different sets of animals exposed to experimental $\mathrm{TBI}$, and following experimental TBI performed by different investigators; thus, we believe reduced expression of THIP-sensitive extrasynaptic $G A B A_{A}$ receptors is a robust and reliable feature of the $\mathrm{CCl}$ model.

Irrespective of these variable results, our data raise an important question: if expression of $\delta$ subunit-containing extrasynaptic $\mathrm{GABA}_{\mathrm{A}}$ receptors is reduced after $\mathrm{CCl}$, why are basal, endogenous tonic currents unaltered? This observation suggests that compensatory mechanisms allow DGGCs to maintain physiological levels of tonic inhibition after $\mathrm{CCl}$ despite fewer receptors. Boychuk et al. (2016) also observed reduced THIP currents after $\mathrm{CCl}$ with paradoxical maintenance of baseline tonic currents that was not because of upregulation of $\alpha 5$ subunit-containing extrasynaptic $\mathrm{GABA}_{A}$ receptors or apparent changes in GAT1 function. Estimates of THIP affinity were similar between control and CCl-ipsi DGGCs, arguing against transition to new $\mathrm{GABA}_{\mathrm{A}}$ receptor subtypes after $\mathrm{CCl}$, but we cannot exclude the emergence of THIP-insensitive, $\alpha 5$ subunit-containing extrasynaptic $\mathrm{GABA}_{\mathrm{A}}$ receptors (Zhan and Nadler, 2009). Basal tonic inhibition after CCl could also be maintained by elevations of ambient GABA levels (Reeves et al., 1997) or post-translational modifications of extrasynaptic receptors affecting GABA affinity, gating kinetics/open probability, single channel conductance, or even the frequency of spontaneous, GABA-independent channel openings (McCartney et al., 2007; Wlodarczyk et al., 2013). Changes in intracellular $\mathrm{Cl}^{-}$concentration after $\mathrm{CCl}$ could also affect basal levels of tonic currents, but this effect would to be minimized by our use of $\mathrm{CsCl}$ pipette solutions during whole-cell recordings. Our data do not distinguish between these possibilities, and defining the factors that maintain basal tonic currents after $\mathrm{CCl}$ despite downregulation of $\delta$ subunit-containing $\mathrm{GABA}_{\mathrm{A}}$ receptors will require additional study.

\section{TBI and synaptic inhibition}

In contrast to the variable reports of TBI effects on tonic GABA currents, reduced synaptic inhibition in DGGCs is more uniformly described after experimental TBI (Mtchedlishvili et al., 2010; Pavlov et al., 2011; Boychuk et al., 2016). Our analysis of sIPSCs indicates a reduction in SIPSC frequency without changes in amplitude or kinetics after $\mathrm{CCl}$, an effect that was limited to the ipsilateral hemisphere at the time point studied (two weeks after $\mathrm{CCl}$ ). This pattern of altered phasic inhibition suggests a presynaptic deficit without alteration of postsynaptic $\mathrm{GABA}_{A}$ receptor expression or function. Significant loss of GABAergic interneurons is consistently observed in many areas of the brain after TBI, including the amygdala, hippocampus, dentate gyrus, and cortex (Pavlov et al., 2011; Almeida-Suhett et al., 2014; Cantu et al., 2014; Huusko et al., 2015). We suspect that loss of interneurons after $\mathrm{CCl}$ contributes to the reduced SIPSC frequency observed, although we did not independently quantify interneuronal loss in our $\mathrm{CCl}$ model and other presynaptic and postsynaptic 
factors may also contribute. Our use of kynurenic acid to block glutamate receptors and isolate $\mathrm{GABA}_{\mathrm{A}}$ receptor currents is expected to reduce sIPSC frequency and could potentially mask glutamate-dependent, compensatory network activity after $\mathrm{CCl}$ (Salin and Prince, 1996; Santhakumar et al., 2001). However, TBI-related changes in both tonic and phasic inhibition have been shown to be independent of glutamate receptor blockade (Pavlov et al., 2011; Gupta et al., 2012).

\section{$\mathrm{GABA}_{B}$ receptor function and TBI}

Tonic inhibition is subject to modulation by a variety of receptor subtypes including insulin receptors, dopamine receptors, and $\mathrm{GABA}_{B}$ receptors (Jin et al., 2011; Connelly et al., 2013a). The effects of GPCRs (and associated signaling pathways) on tonic inhibition are cell-type specific and depend on the type of extrasynaptic $\mathrm{GABA}_{\mathrm{A}}$ receptor subunits expressed. For example, tonic inhibition in nigrostriatal D1 + and D2+ medium spiny neurons (MSNs) display distinct and reciprocal patterns of modulation. D2-like receptors $\left(\mathrm{G}_{\mathrm{i} / \mathrm{o}}\right)$, which decrease PKA activity, reduce tonic currents of D2+ MSNs. In contrast, tonic currents of D1+ MSNs are insensitive to decreased PKA activity, but are increased by $D 1$-like receptors $\left(G_{s}\right)$ that stimulate PKA activity (Janssen et al., 2009). In hippocampus and thalamus, $G A B A_{B}$ receptors $\left(G_{i / o}\right)$ enhance tonic inhibition in cells expressing $\mathrm{GABA}_{\mathrm{A}}$ receptor $\delta$ subunits (thalamocortical cells, DGGCs, and interneurons), but not in CA1 pyramidal cells (that mainly express $\alpha 5$ subunit-containing receptors) nor $\delta$ subunit knock-out mice (Glykys et al., 2008; Connelly et al., 2013b; Tao et al., 2013). Modulation by GPCRs and signaling pathways are mechanisms allowing neurons to dynamically

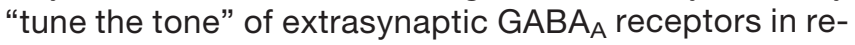
sponse to neuromodulators or ongoing neural activity. These effects will develop and operate over minutes, in contrast to other mechanisms that rapidly (seconds) regulate tonic conductance (e.g., nonvesicular GABA release, voltage-dependent properties of $\mathrm{GABA}_{A}$ receptors; Pavlov et al., 2009; Ransom et al., 2010, 2013).

Enhancement of tonic inhibition by $\mathrm{GABA}_{B}$ receptors is predicted to reduce the response of DGGCs to excitatory synaptic inputs with consequences for information flow through hippocampus and hippocampal network activity (Pavlov et al., 2009; Connelly et al., 2013b). GABA ${ }_{B}$ receptors are believed to enhance tonic inhibition via increased surface expression of $\mathrm{GABA}_{\mathrm{A}}$ receptors, including those containing $\delta$ and $\beta 3$ subunits (Kuczewski et al., 2011; Parga and Ransom, 2018). Activation of postsynaptic $\mathrm{GABA}_{\mathrm{B}}$ receptors, localized to extrasynaptic portions of membrane (Kulik et al., 2003), requires robust patterns of presynaptic activity and GABA spillover (Scanziani, 2000; Lüscher and Slesinger, 2010). It is hypothesized that periodic increases in extracellular GABA during pathophysiological neural activity, such as interictal bursting and seizures (Perreault et al., 1992; During and Spencer, 1993; Markwardt et al., 2009), could activate postsynaptic $\mathrm{GABA}_{\mathrm{B}}$ receptors to provide adaptive, feed-forward increases in tonic inhibition. Our data indicate that modulation of tonic inhibition by $\mathrm{GABA}_{B}$ receptors is markedly attenuated after $\mathrm{CCl}$. The enhancement of tonic inhibition by $\mathrm{GABA}_{\mathrm{B}}$ receptors (mediated by $\mathrm{G}_{\mathrm{i} / \mathrm{o}}$ signaling) could be occluded after TBI when cAMP levels and PKA activity are reduced in hippocampus (Atkins et al., 2007; Titus et al., 2013a). However, TBI-associated changes in cAMP/ PKA activity recover within days of injury so are not expected to contribute to the deficits in $\mathrm{GABA}_{B}$ modulation of tonic currents we observed two weeks after injury. Moreover, our immunohistochemical analysis and direct measurements of $\mathrm{GABA}_{\mathrm{B}}$ receptor-activated $\mathrm{K}^{+}$currents demonstrate reduced expression and function of $G A B A_{B}$ receptors after $\mathrm{CCl}$. This downregulation explains, at least in part, the impaired modulation of tonic currents after $\mathrm{CCl}$. It remains to be shown whether synaptic $\mathrm{GABA}_{\mathrm{B}}$ responses/slow IPSCs are also affected by $\mathrm{CCl}$, but altered $G_{A B A}$ expression and GIRK channel function is predicted to significantly impact behavior of DGGCs independent of modulatory actions on tonic inhibition (Lüscher and Slesinger, 2010). To the best of our knowledge, this study is the first description of functional deficits of $G_{A B A_{B}}$ receptors after experimental TBI (but see Drexel et al., 2015).

\section{Functional implications for altered GABAergic signaling after TBI}

Our findings in the $\mathrm{CCl}$ model are most relevant to severe TBI, defined by prolonged $(>24 \mathrm{~h}$ ) loss of consciousness or structural brain abnormalities/hemorrhage, and severe TBI confers a high risk of developing epilepsy (second only to subarachnoid hemorrhage as risk factor for acquired epilepsy; Annegers et al., 1998; Garga and Lowenstein, 2006). In addition to deficits related to neuroanatomical injuries and seizures, sequelae of severe TBI frequently includes cognitive dysfunction and mood disorders (Morissette et al., 2011; Paterno et al., 2017). Numerous cellular and molecular processes contribute to the complex pathophysiology and outcome of TBI, including neuronal death (Huusko and Pitkänen, 2014), NMDA receptor function/CAMKII expression (Schwarzbach et al., 2006), mossy fiber sprouting (Hunt et al., 2009), intracellular signaling pathways (Yang et al., 1993; Kobori et al., 2014), immune/inflammatory mechanisms (Schwarzmaier and Plesnila, 2014), and alterations in GABAergic signaling (Hunt et al., 2013). The persistent effects of CCl on expression and regulation of $\delta$ subunit-containing extrasynaptic $\mathrm{GABA}_{\mathrm{A}}$ receptors described here are of particular interest, because tonic inhibition has established effects on many of the physiological and pathophysiological processes affected by TBI, including learning and memory (Cheng et al., 2006), anxiety-related and mood-related behaviors (Smith et al., 2007), and epileptic seizures (Chuang and Reddy, 2018).

Functional deficits in $\delta$ subunit-containing $\mathrm{GABA}_{\mathrm{A}}$ receptors and $\mathrm{GABA}_{B}$ receptors after $\mathrm{CCl}$ are predicted to alter cellular/network activity and behavior. Furthermore, the consequences of these functional deficits are predicted to be greatest during robust neural activity accompanied by transient elevations of GABA concentration. Because only a fraction of extrasynaptic $\mathrm{GABA}_{A}$ receptors are active under basal conditions, activity-dependent increases in [GABA] will activate additional, unbound 
receptors and increase tonic inhibition (Wei et al., 2003; Ransom et al., 2013). Reduced expression of both $G_{A B A}$ and $\mathrm{GABA}_{\mathrm{B}}$ receptors after $\mathrm{CCl}$ will impair the ability of DGGCs to rapidly adjust inhibitory tone in response to ongoing neural activity. These impairments will affect the integration and processing of inputs arriving from cortex, recurrent mossy fibers, and local interneurons and promote hyperexcitability. Although our data are limited to DGGCs, the changes in GABAergic signaling caused by $\mathrm{CCl}$ are expected to contribute to broader hippocampal dysfunction and the clinical consequences of TBI, including alterations in synaptic plasticity that can impact memory and epileptogenesis (Titus et al., 2013b; Wu et al., 2014). $\mathrm{GABA}_{\mathrm{A}}$ receptor $\delta$ subunits are also an emerging therapeutic target for mood disorders, and neurosteroid analogs that potentiate tonic inhibition (brexanolone, SAGE-217) are effective treatments for major depression and postpartum depression (Kanes et al., 2017; GunduzBruce et al., 2019). The development of mood disorder after TBI likely involves more widespread networks than just the hippocampus, and in situ hybridization experiments indicating reduced expression of $\delta$ subunits in cortex and thalamus after experimental TBI support a possible role of $\delta$ subunit in post-TBI depression (Drexel et al., 2015).

Defining the cellular and molecular changes triggered by TBI and their relative contribution to behavioral and cognitive outcomes and epileptogenesis/seizures is a daunting challenge but is essential to develop novel, effective strategies and interventions to improve outcomes. Of the myriad effects of TBI, those that occur reliably and persist beyond the acute phase deserve the greatest attention and represent opportunity for therapeutic intervention. Our data and prior work compel us to conclude that reduced expression of extrasynaptic $\mathrm{GABA}_{A}$ receptors and $\mathrm{GABA}_{\mathrm{B}}$ receptors are reliable and persistent consequences of TBI. Future work defining the proximal factors that generate persistent functional changes after TBI could inform strategies to limit the cellular and molecular changes that underlie cognitive dysfunction and the development of epilepsy.

\section{References}

Almeida-Suhett CP, Prager EM, Pidoplichko V, Figueiredo TH, Marini AM, Li Z, Eiden LE, Braga MF (2014) Reduced GABAergic inhibition in the basolateral amygdala and the development of anxietylike behaviors after mild traumatic brain injury. PLoS One 9: e102627.

Annegers JF, Hauser WA, Coan SP, Rocca WA (1998) A populationbased study of seizures after traumatic brain injuries. $\mathrm{N}$ Engl $\mathrm{J}$ Med 338:20-24.

Atkins CM, Oliva AA Jr, Alonso OF, Pearse DD, Bramlett HM, Dietrich WD (2007) Modulation of the cAMP signaling pathway after traumatic brain injury. Exp Neurol 208:145-158.

Belelli D, Harrison NL, Maguire J, Macdonald RL, Walker MC, Cope DW (2009) Extrasynaptic GABAA receptors: form, pharmacology, and function. J Neurosci 29:12757-12763.

Boychuk JA, Butler CR, Halmos KC, Smith BN (2016) Enduring changes in tonic GABAA receptor signaling in dentate granule cells after controlled cortical impact brain injury in mice. Exp Neurol 277:178-189.
Cantu D, Walker K, Andresen L, Taylor-Weiner A, Hampton D, Tesco G, Dulla CG (2014) Traumatic brain injury increases cortical glutamate network activity by compromising GABAergic control. Cereb Cortex 25:2306-2320.

Cheng VY, Martin LJ, Elliott EM, Kim JH, Mount HT, Taverna FA, Roder JC, Macdonald JF, Bhambri A, Collinson N, Wafford KA,

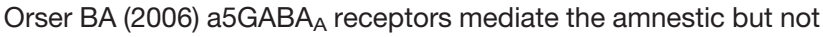
sedative-hypnotic effects of the general anesthetic etomidate. $J$ Neurosci 26:3713-3720.

Chuang SH, Reddy DS (2018) Genetic and molecular regulation of extrasynaptic GABA-A receptors in the brain: therapeutic insights for epilepsy. J Pharmacol Exp Ther 364:180-197.

Clarkson AN, Huang BS, Macisaac SE, Mody I, Carmichael ST (2010) Reducing excessive GABA-mediated tonic inhibition promotes functional recovery after stroke. Nature 468:305-309.

Colombo E, Farina C (2016) Astrocytes: key regulators of neuroinflammation. Trends Immunol 37:608-620.

Connelly WM, Errington AC, Di Giovanni G, Crunelli V (2013a) Metabotropic regulation of extrasynaptic GABAA receptors. Front Neural Circuits 7:171.

Connelly WM, Fyson SJ, Errington AC, McCafferty CP, Cope DW, Di Giovanni G, Crunelli V (2013b) $\mathrm{GABA}_{B}$ receptors regulate extrasy-

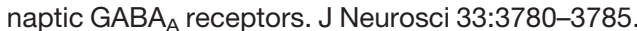

Cope DW, Di Giovanni G, Fyson SJ, Orbán G, Errington AC, Lorincz ML, Gould TM, Carter DA, Crunelli V (2009) Enhanced tonic GABAA inhibition in typical absence epilepsy. Nat Med 15:13921398.

Drexel M, Puhakka N, Kirchmair E, Hörtnagl H, Pitkänen A, Sperk G (2015) Expression of GABA receptor subunits in the hippocampus and thalamus after experimental traumatic brain injury. Neuropharmacology 88:122-133.

During MJ, Spencer DD (1993) Extracellular hippocampal glutamate and spontaneous seizure in the conscious human brain. Lancet 341:1607-1610.

Farrant M, Nusser Z (2005) Variations on an inhibitory theme: phasic and tonic activation of $\operatorname{GABA}(\mathrm{A})$ receptors. Nat Rev Neurosci 6:215-229.

Garga N, Lowenstein DH (2006) Posttraumatic epilepsy: a major problem in desperate need of major advances. Epilepsy Curr 6:1-5.

Glushakov AV, Glushakova OY, Doré S, Carney PR, Hayes RL (2016) Animal models of posttraumatic seizures and epilepsy. Methods Mol Biol 1462:481-519.

Glykys J, Mody I (2007) The main source of ambient GABA responsible for tonic inhibition in the mouse hippocampus. J Physiol 582:1163-1178.

Glykys J, Mann EO, Mody I (2008) Which GABA(A) receptor subunits are necessary for tonic inhibition in the hippocampus? J Neurosci 28:1421-1426.

Guerriero RM, Giza CC, Rotenberg A (2015) Glutamate and GABA imbalance following traumatic brain injury. Curr Neurol Neurosci Rep 15:27.

Gunduz-Bruce H, Silber C, Kaul I, Rothschild AJ, Riesenberg R, Sankoh AJ, Li H, Lasser R, Zorumski CF, Rubinow DR, Paul SM, Jonas J, Doherty JJ, Kanes SJ (2019) Trial of SAGE-217 in patients with major depressive disorder. N Engl J Med 381:903-911.

Gupta A, Elgammal FS, Proddutur A, Shah S, Santhakumar V (2012) Decrease in tonic inhibition contributes to increase in dentate semilunar granule cell excitability after brain injury. J Neurosci 32:2523-2537.

Huang D, Huang S, Peers C, Du X, Zhang H, Gamper N (2015) GABAB receptors inhibit low-voltage activated and high-voltage activated $\mathrm{Ca}(2+)$ channels in sensory neurons via distinct mechanisms. Biochem Biophys Res Commun 465:188-193.

Hunt RF, Scheff SW, Smith BN (2009) Posttraumatic epilepsy after controlled cortical impact injury in mice. Exp Neurol 215:243-252.

Hunt RF, Boychuk JA, Smith BN (2013) Neural circuit mechanisms of post-traumatic epilepsy. Front Cell Neurosci 7:89. 
Huusko N, Pitkänen A (2014) Parvalbumin immunoreactivity and expression of GABAA receptor subunits in the thalamus after experimental TBI. Neuroscience 267:30-45.

Huusko N, Romer C, Ndode-Ekane XE, Lukasiuk K, Pitkanen A (2015) Loss of hippocampal interneurons and epileptogenesis: a comparison of two animal models of acquired epilepsy. Brain Struct Funct 220:153-191.

Isaacson JS, Solís JM, Nicoll RA (1993) Local and diffuse synaptic actions of GABA in the hippocampus. Neuron 10:165-175.

Janssen MJ, Ade KK, Fu Z, Vicini S (2009) Dopamine modulation of GABA tonic conductance in striatal output neurons. J Neurosci 29:5116-5126.

Jin Z, Jin Y, Kumar-Mendu S, Degerman E, Groop L, Birnir B (2011) Insulin reduces neuronal excitability by turning on $\mathrm{GABA}(\mathrm{A})$ channels that generate tonic current. PLoS One 6:e16188.

Kanes S, Colquhoun H, Gunduz-Bruce H, Raines S, Arnold R, Schacterle A, Doherty J, Epperson CN, Deligiannidis KM, Riesenberg R, Hoffmann E, Rubinow D, Jonas J, Paul S, MeltzerBrody S (2017) Brexanolone (SAGE-547 injection) in post-partum depression: a randomised controlled trial. Lancet 390:480-489.

Kharlamov EA, Lepsveridze E, Meparishvili M, Solomonia RO, Lu B, Miller ER, Kelly KM, Mtchedlishvili Z (2011) Alterations of GABA(A) and glutamate receptor subunits and heat shock protein in rat hippocampus following traumatic brain injury and in posttraumatic epilepsy. Epilepsy Res 95:20-34.

Kobori N, Moore AN, Dash PK (2014) Altered regulation of protein kinase $A$ activity in the medial prefrontal cortex of normal and brain injured animals actively engaged in a working memory task. J Neurotrauma 172:293-302.

Koepp MJ, Edwards M, Collins J, Farrel F, Smith S (2005) Status epilepticus and tiagabine therapy revisited. Epilepsia 46:1625-1632.

Kuczewski N, Fuchs C, Ferrand N, Jovanovic JN, Gaiarsa JL, Porcher C (2011) Mechanism of GABAB receptor-induced BDNF secretion and promotion of GABAA receptor membrane expression. J Neurochem 118:533-545.

Kulik A, Vida I, Luján R, Haas CA, López-Bendito G, Shigemoto R, Frotscher M (2003) Subcellular localization of metabotropic GABA (B) receptor subunits $\mathrm{GABA}(\mathrm{B} 1 \mathrm{a} / \mathrm{b})$ and $\mathrm{GABA}(\mathrm{B} 2)$ in the rat hippocampus. J Neurosci 23:11026-11035.

Lüscher C, Slesinger PA (2010) Emerging roles for G protein-gated inwardly rectifying potassium (GIRK) channels in health and disease. Nat Rev Neurosci 11:301-315.

Maguire JL, Stell BM, Rafizadeh M, Mody I (2005) Ovarian cyclelinked changes in $\mathrm{GABA}(\mathrm{A})$ receptors mediating tonic inhibition alter seizure susceptibility and anxiety. Nat Neurosci 8:797-804.

Markwardt SJ, Wadiche Jl, Overstreet-Wadiche LS (2009) Input-specific GABAergic signaling to newborn neurons in adult dentate gyrus. J Neurosci 29:15063-15072.

McCartney MR, Deeb TZ, Henderson TN, Hales TG (2007) Tonically active GABAA receptors in hippocampal pyramidal neurons exhibit constitutive GABA-independent gating. Mol Pharmacol 71:539-548.

Meera P, Wallner M, Otis TS (2011) Molecular basis for the high THIP/gaboxadol sensitivity of extrasynaptic GABA(A) receptors. J Neurophysiol 106:2057-2064.

Morissette SB, Woodward M, Kimbrel NA, Meyer EC, Kruse MI, Dolan S, Gulliver SB, Morissette SB, Woodward M, Kimbrel NA, Meyer EC, Kruse MI, Dolan S, Gulliver SB (2011) Deployment-related TBI, persistent postconcussive symptoms, PTSD, and depression in OEF/OIF veterans. Rehabil Psychol 56:340-350.

Mortensen M, Smart TG (2006) Extrasynaptic ab subunit GABA ${ }_{A}$ receptors on rat hippocampal pyramidal neurons. J Physiol 577:841-856.

Mortensen M, Ebert B, Wafford K, Smart TG (2010) Distinct activities of GABA agonists at synaptic- and extrasynaptic-type GABAA receptors. J Physiol 588:1251-1268.

Mtchedlishvili Z, Lepsveridze E, Xu H, Kharlamov EA, Lu B, Kelly KM (2010) Increase of GABAA receptor-mediated tonic inhibition in dentate granule cells after traumatic brain injury. Neurobiol Dis 38:464-475.
Otis TS, De Koninck Y, Mody I (1993) Characterization of synaptically elicited GABAB responses using patch-clamp recordings in rat hippocampal slices. J Physiol 463:391-407.

Padgett CL, Slesinger PA (2010) GABAB receptor coupling to G-proteins and ion channels. Adv Pharmacol 58:123-147.

Parga A, Ransom CB (2018) Modulation of extrasynaptic GABA receptor function in dentate gyrus granule cells by $G A B A_{B}$ receptors and severe TBI. In: Society for neuroscience. San Diego: Society for Neuroscience Annual Meeting.

Patel B, Bright DP, Mortensen M, Frølund B, Smart TG (2016) Context-dependent modulation of GABAAR-mediated tonic currents. J Neurosci 36:607-621.

Patenaude C, Chapman CA, Bertrand S, Congar P, Lacaille JC (2003) GABAB receptor- and metabotropic glutamate receptordependent cooperative long-term potentiation of rat hippocampal GABAA synaptic transmission. J Physiol 553:155-167.

Paterno R, Folweiler KA, Cohen AS (2017) Pathophysiology and treatment of memory dysfunction after traumatic brain injury. Curr Neurol Neurosci Rep 17:52.

Pavlov I, Savtchenko LP, Kullmann DM, Semyanov A, Walker MC (2009) Outwardly rectifying tonically active GABAA receptors in pyramidal cells modulate neuronal offset, not gain. J Neurosci 29:15341-15350.

Pavlov I, Huusko N, Drexel M, Kirchmair E, Sperk G, Pitkänen A, Walker MC (2011) Progressive loss of phasic, but not tonic, GABAA receptor-mediated inhibition in dentate granule cells in a model of post-traumatic epilepsy in rats. Neuroscience 194:208219.

Perreault P, Avoli M, Perreault P, Avoli M (1992) 4-aminopyridine-induced epileptiform activity and a GABA-mediated long-lasting depolarization in the rat hippocampus. J Neurosci 12:104-115.

Perry DC, Sturm VE, Peterson MJ, Pieper CF, Bullock T, Boeve BF, Miller BL, Guskiewicz KM, Berger MS, Kramer JH, Welsh-Bohmer KA (2016) Association of traumatic brain injury with subsequent neurological and psychiatric disease: a meta-analysis. J Neurosurg 124:511-526.

Raible DJ, Frey LC, Cruz Del Angel Y, Russek SJ, Brooks-Kayal AR (2012) GABA(A) receptor regulation after experimental traumatic brain injury. J Neurotrauma 29:2548-2554.

Ransom CB, Wu Y, Richerson GB (2010) Postdepolarization potentiation of GABAA receptors: a novel mechanism regulating tonic conductance in hippocampal neurons. J Neurosci 30:7672-7684.

Ransom CB, Tao W, Wu Y, Spain WJ, Richerson GB (2013) Rapid regulation of tonic GABA currents in cultured rat hippocampal neurons. J Neurophysiol 109:803-812.

Reeves TM, Lyeth BG, Phillips LL, Hamm RJ, Povlishock JT, Reeves TM, Lyeth BG, Phillips LL, Hamm RJ, Povlishock JT (1997) The effects of traumatic brain injury on inhibition in the hippocampus and dentate gyrus. Brain Res 757:119-132.

Salin PA, Prince DA (1996) Spontaneous GABAA receptor-mediated inhibitory currents in adult rat somatosensory cortex. J Neurophysiol 75:1573-1588.

Santhakumar V, Ratzliff ADH, Jeng J, Toth Z, Soltesz I (2001) Longterm hyperexcitability in the hippocampus after experimental head trauma. Ann Neurol 50:708-717.

Santhakumar V, Hanchar HJ, Wallner M, Olsen RW, Otis TS (2006) Contributions of the GABAA receptor a6 subunit to phasic and tonic inhibition revealed by a naturally occurring polymorphism in the a6 gene. J Neurosci 26:3357-3364.

Scanziani M (2000) GABA spillover activates postsynaptic GABA(B) receptors to control rhythmic hippocampal activity. Neuron 25:673-681.

Schneider Gasser EM, Straub CJ, Panzanelli P, Weinmann O, Sassoe-Pognetto M, Fritschy JM (2006) Immunofluorescence in brain sections: simultaneous detection of presynaptic and postsynaptic proteins in identified neurons. Nat Protoc 1:1887-1897.

Schwarzbach E, Bonislawski DP, Xiong G, Cohen AS (2006) Mechanisms underlying the inability to induce area CA1 LTP in the mouse after traumatic brain injury. Hippocampus 16:541-550. 
Schwarzmaier SM, Plesnila N (2014) Contributions of the immune system to the pathophysiology of traumatic brain injury - evidence by intravital microscopy. Front Cell Neurosci 8:358.

Smith SS, Shen H, Gong QH, Zhou X (2007) Neurosteroid regulation of $\mathrm{GABA}(\mathrm{A})$ receptors: focus on the alpha4 and delta subunits. Pharmacol Ther 116:58-76.

Takahashi T, Kajikawa Y, Tsujimoto T (1998) G-Protein-coupled modulation of presynaptic calcium currents and transmitter release by a GABAB receptor. J Neurosci 18:3138-3146.

Tao W, Higgs MH, Spain WJ, Ransom CB (2013) Postsynaptic $\mathrm{GABA}_{\mathrm{B}}$ receptors enhance extrasynaptic $\mathrm{GABA}_{\mathrm{A}}$ receptor function in dentate gyrus granule cells. J Neurosci 33:3738-3743.

Titus DJ, Furones C, Kang Y, Atkins CM (2013a) Age-dependent alterations in CAMP signaling contribute to synaptic plasticity deficits following traumatic brain injury. Neuroscience 231:182194.

Titus DJ, Sakurai A, Kang Y, Furones C, Jergova S, Santos R, Sick TJ, Atkins CM (2013b) Phosphodiesterase inhibition rescues chronic cognitive deficits induced by traumatic brain injury. $\mathrm{J}$ Neurosci 33:5216-5226.

Wei W, Zhang N, Peng Z, Houser CR, Mody I (2003) Perisynaptic localization of delta subunit-containing GABA(A) receptors and their activation by GABA spillover in the mouse dentate gyrus. J Neurosci 23:10650-10661.

Wlodarczyk Al, Sylantyev S, Herd MB, Kersanté F, Lambert JJ, Rusakov DA, Linthorst AC, Semyanov A, Belelli D, Pavlov I, Walker MC (2013) GABA-independent GABAA receptor openings maintain tonic currents. J Neurosci 33:3905-3914.

Wu Z, Guo Z, Gearing M, Chen G (2014) Tonic inhibition in dentate gyrus impairs long-term potentiation and memory in an Alzheimer's disease model. Nat Commun 5:4159.

Yang K, Taft WC, Dixon CE, Todaro CA, Yu RK, Hayes RL (1993) Alterations of protein kinase $\mathrm{C}$ in rat hippocampus following traumatic brain injury. J Neurotrauma 10:287-295.

Zhan RZ, Nadler JV (2009) Enhanced tonic GABA current in normotopic and hilar ectopic dentate granule cells after pilocarpine-induced status epilepticus. J Neurophysiol 102:670-681. 